\title{
Skeletal muscle as an experimental model of choice to study tissue aging and rejuvenation
}

\author{
Jessy Etienne(D, Chao Liu, Colin M. Skinner, Michael J. Conboy and Irina M. Conboy* (1)
}

\begin{abstract}
Skeletal muscle is among the most age-sensitive tissues in mammal organisms. Significant changes in its resident stem cells (i.e., satellite cells, SCs), differentiated cells (i.e., myofibers), and extracellular matrix cause a decline in tissue homeostasis, function, and regenerative capacity. Based on the conservation of aging across tissues and taking advantage of the relatively well-characterization of the myofibers and associated SCs, skeletal muscle emerged as an experimental system to study the decline in function and maintenance of old tissues and to explore rejuvenation strategies. In this review, we summarize the approaches for understanding the aging process and for assaying the success of rejuvenation that use skeletal muscle as the experimental system of choice. We further discuss (and exemplify with studies of skeletal muscle) how conflicting results might be due to variations in the techniques of stem cell isolation, differences in the assays of functional rejuvenation, or deciding on the numbers of replicates and experimental cohorts.
\end{abstract}

Keywords: Aging, Myogenesis, Stem cells, Niche, Tissue repair, Inflammation, Signaling pathways, Epigenome, Satellite cells, Rejuvenation

\section{Background}

Several theories of aging have been proposed: cellular senescence [1], accumulation of mutations [2], antagonistic pleiotropy [3], disposable soma [4], deteriorated proteostasis [5], or telomere attrition [6]. While relevant and valid in many instances, each of these theories alone does not explain the rapid and robust rejuvenation of old tissues observed in heterochronic parabioses and blood exchange studies [7-11]. An alternative theory that fits both the aging and the rejuvenation data [12] suggests that aging is caused primarily by the functional (and notably, experimentally reversible) inactivation of resident stem cells, which precipitates deteriorated tissue maintenance and repair and leads to the loss of organ homeostasis [13]. The damaged and unrepaired tissues suffer changes in their biochemistry, including the molecular crosstalk with resident stem cells, which further inhibits productive, regenerative responses. The inflammatory and fibrotic secretome can then propagate systemically, affecting the entire organism [10, 14-23]. This decline in homeostatic functional integrity causes age-

\footnotetext{
* Correspondence: iconboy@berkeley.edu

Department of Bioengineering and QB3 Institute, University of California, Berkeley, Berkeley, CA 94720-3220, USA
}

associated diseases, the degenerative and inflammatory disorders of the muscle, brain, liver, and bone, diminished immune responses, and increased susceptibility to infections, cancers, cardiovascular diseases, and metabolic diseases (e.g., type II diabetes) [24]. Figure 1 illustrates the aboveintroduced theory of aging.

Skeletal muscle (note that "muscle" does not include smooth and cardiac muscle in this review) accounts for almost $40 \%$ of the total adult human body mass. This tissue is indispensable for vital functions such as respiration, locomotion, and voluntary movements and is among the most age-sensitive in mammals. Aging muscle loses its ability to adapt its morphological, biochemical, biophysical, and molecular properties to loads and use. With advanced age, interventions such as exercise do not efficiently reverse the rapid loss of muscle mass resulting from disuse atrophy and systemic diseases. Numerous age-associated changes have been investigated: fiber atrophy [25-27], increase in apoptosis [28], DNA damage [29, 30], heterochromatin marks [31], reduced protein synthesis [32, 33], autophagic degradation [34], lysosomal dysfunction characterized by lipofuscin accumulation [35, 36], accumulation of advanced glycation end-products [37], insoluble polyubiquitylated

(c) The Author(s). 2020 Open Access This article is distributed under the terms of the Creative Commons Attribution 4.0 International License (http://creativecommons.org/licenses/by/4.0/), which permits unrestricted use, distribution, and 


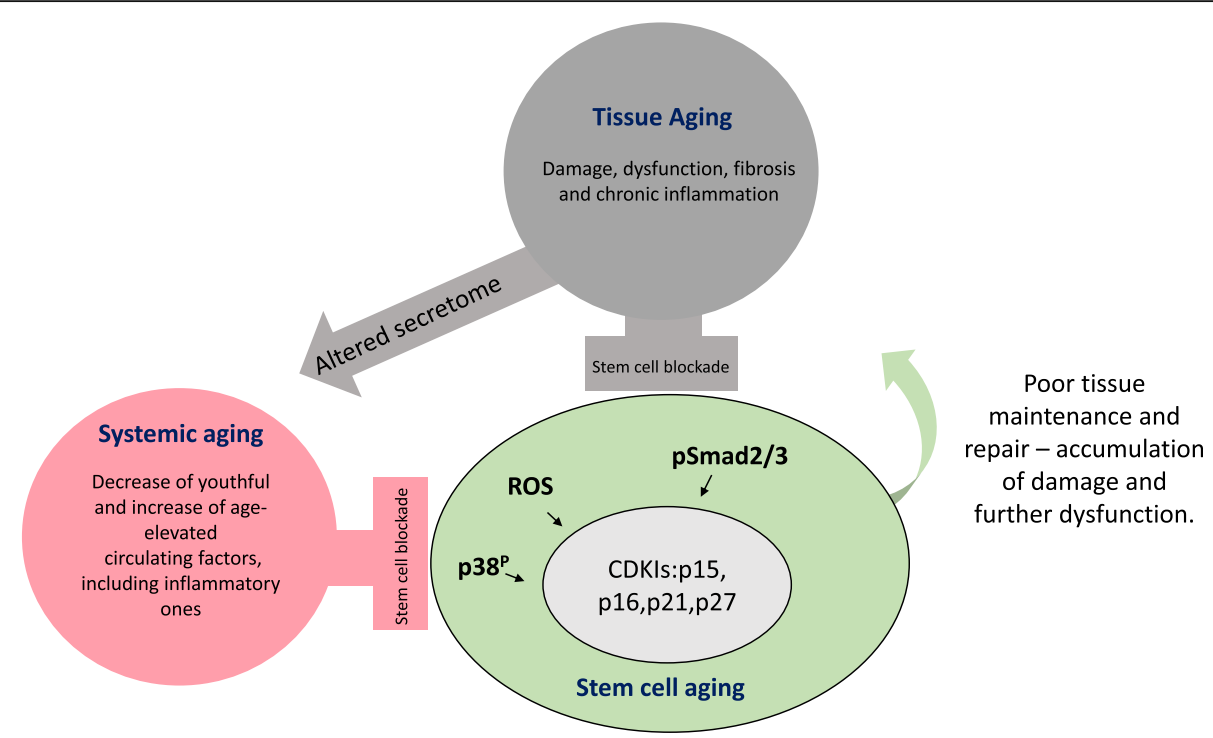

Fig. 1 Fundamental theory of progressive tissue aging that fits with the phenomena of rapid experimental rejuvenation. Increasing with chronological age, damage to differentiated soma - tissue niches of stem cells blocks regenerative responses through deregulation of cell-niche crosstalks. With worsened regenerations, tissues become more damaged (increase in inflammation and fibrosis) and their secretome changes thereby altering the composition of systemic milieu, affecting tissues at a distance, and further inhibiting the capacity of adult stem cells to maintain and repair the tissues

proteins [38], changes in microRNA expression [39], and altered nuclear shape and spatial disorganization of nuclei [40]. These age-specific parameters are not unique to muscle and manifest more generally, in other organs and tissues, such as the immune system, CNS, bone, skin, and liver $[41,42]$. Similarly, the decline in numbers and functional activation seen with muscle satellite cells (SCs) are also seen in other tissues such as blood, brain, bone, and liver $[41,42]$. The age-specific changes in the resident stem cell pools diminish the regenerative potential that is needed to compensate for tissue loss due to attrition or injury. As typical of tissue aging, the aged muscle becomes infiltrated by adipose tissue and fibrosis, shows decreased capillarization, and is characterized by chronic inflammation. Altogether, these changes result in a progressive reduction in myofiber size and number that collectively are seen as a progressive decline in muscle mass, cross-sectional area, and strength, a phenomenon known as sarcopenia.

Muscle is relatively accessible for ectopic gene expression, given that it is a non-vital tissue with a good ability to uptake gene constructs after single or repeated injections into the tissue or through systemic delivery. Using screens for native gene expression and gene reporters, the markers and biochemical regulators of SCs have been identified and characterized [43]. Additional methods, including tissue histology, biochemistry, cell isolation and characterization by function, and gene expression-omics studies, have allowed decrypting age-specific SCs properties, changes in differentiated myofibers, and the dynamics between SCs and their muscle niches. The SCs niche controls the maintenance and breakage of quiescence, decisions to self- renew or differentiate, and asymmetric versus symmetric divisions. In SCs, chromatin adopts bivalent states to facilitate rapid differentiation in response to external factors, and metabolism adapts to support particular needs. Stem cell niche control of SCs is age-specific and is generally conserved between adult tissue stem cells [41, 42].

This review summarizes current approaches that used skeletal muscle for improving our understanding of the crosstalk between adult stem cells and their niches, which, when altered by aging, leads to reduced tissue maintenance and repair. We also discuss how tissue rejuvenation might be pursued. We further elaborate on differences in the experimental design in the field of aging and rejuvenation that might have led to conflicting results, and we point out critical steps for ensuring robust experimental outcomes.

\section{Life-long stem cell persistence, age-specific dysfunction, and loss of heterogeneity}

Muscle is capable of active repair in response to daily wear and tear, intense exercises, or injuries. Unfortunately, there is a noticeable decline in muscle regeneration and performance after 40 years, and this tissue becomes typically dysfunctional after the seventh decade, characterized by severe loss of muscle mass or sarcopenia [44-48]. Muscle regeneration relies on the adult muscle stem cells, also called satellite cells (SCs) due to their location around the periphery of the sarcolemma, under the basal lamina of each mature myofiber. Decades of studies have provided abundant information on the SC markers, tissue location, signaling 
pathways that control their function, and the age-imposed changes in any of the above [7, 8, 49-53].

The inherent heterogeneity of the SC pool might have led to conflicting results in the aging field because different groups employ different approaches for SCs identification and isolation (summarized in Fig. 2), thus analyzing different subsets of the heterogeneous population which have different properties. Historically, SCs were first identified and studied in muscle cryosection by electron microscopy [54] and are currently studied through immunofluorescence imaging. Since their first observation in the tibialis anticus (anterior) muscle of the frog [54], several markers have allowed SCs identification in many animals: human, mouse, monkey, pig, chick, salamander, frog, and zebrafish [55-57]. These adult stem cell markers include Barx2 [58], c-Met [59], calcitonin receptor [60], caveolae-forming protein caveolin 1 [61], CD34 [51, 62], CD56 [63, 64], CXCR4 [65, 66], Emerin [61], Lamin A/C [40], M-Cadherin [51], NCAM [67], Notch1 [67], VCAM1 [68], Pax3 [69], syndecan3 [70], syndecan4 [67, 70], and Sca1 [66], but by far, Pax7 [71] is the most widely used and evolutionarily conserved SC marker for fetal and adult SCs [72].

Most of the studies investigating aged SCs properties (e.g., proliferation and differentiation capacities) use fluorescence-activated cell sorting (FACS) on the broadly expressed CXCR4, CD34, or additional myogenic markers (e.g., M-Cadherin, alpha7-integrin, syndecan4, VCAM1 and ITGB1), while negatively selecting against CD45 leukocytes, CD31 endothelial cells, and Sca1-expressing cells. Cell sorting can be damaging for cell viability and function and, more importantly, enriches for a sub-population of
SCs, both focusing on that population and yet limiting the study only to that subset [53,66, 68, 73-75]. Alternative methods, such as density gradient purification, requires multiple centrifugations and also can compromise cell viability and function and require high starting cell numbers, thus calling for experimental injury by myotoxins or cardiotoxin, or expansion of the cells in culture, thus allowing further deviation from in vivo properties and gene expression [76].

Methods that do not limit the study to a subset consist of chopping the muscle into small pieces and, after mesh filtration and/or pre-plating on plastic culture dishes, expansion of the fewer adherent cells in Ham's F-10 Nutrient Mixture (F-10), 20\% FBS, 2.5-5 ng/ml bFGF [52, 77]. While in this bulk preparation, no sub-population is excluded, SCs are contaminated with other cells, including fibroblasts, endothelial cells, and macrophages. Such contamination with irrelevant cell types may be minimized by the culture of single myofiber explants or two-step enzymatic dissociation of myofibers with their associated SCs. The type of enzyme depends on the species and digestion methods [78-80], but after removal of the more adherent fibroblasts (for instance, by pre-plating on uncoated tissue culture dishes), the SC myogenic pool reaches $95-99 \%$ of purity and the stem cell properties, gene expression, and heterogeneity are preserved [78, 81-87].

Within the muscle, around $85 \%$ of SCs are located in proximity to blood vessels [88], and these cells display heterogeneities of metabolism, the ability for long-term renewal versus differentiation, and expression of Pax7 or Myf5. Quiescent SCs exist as a continuum from $\operatorname{Pax} 7^{\text {low }}$ cells that are primed for cell-cycle entry to Pax $7^{\text {high }}$ cells

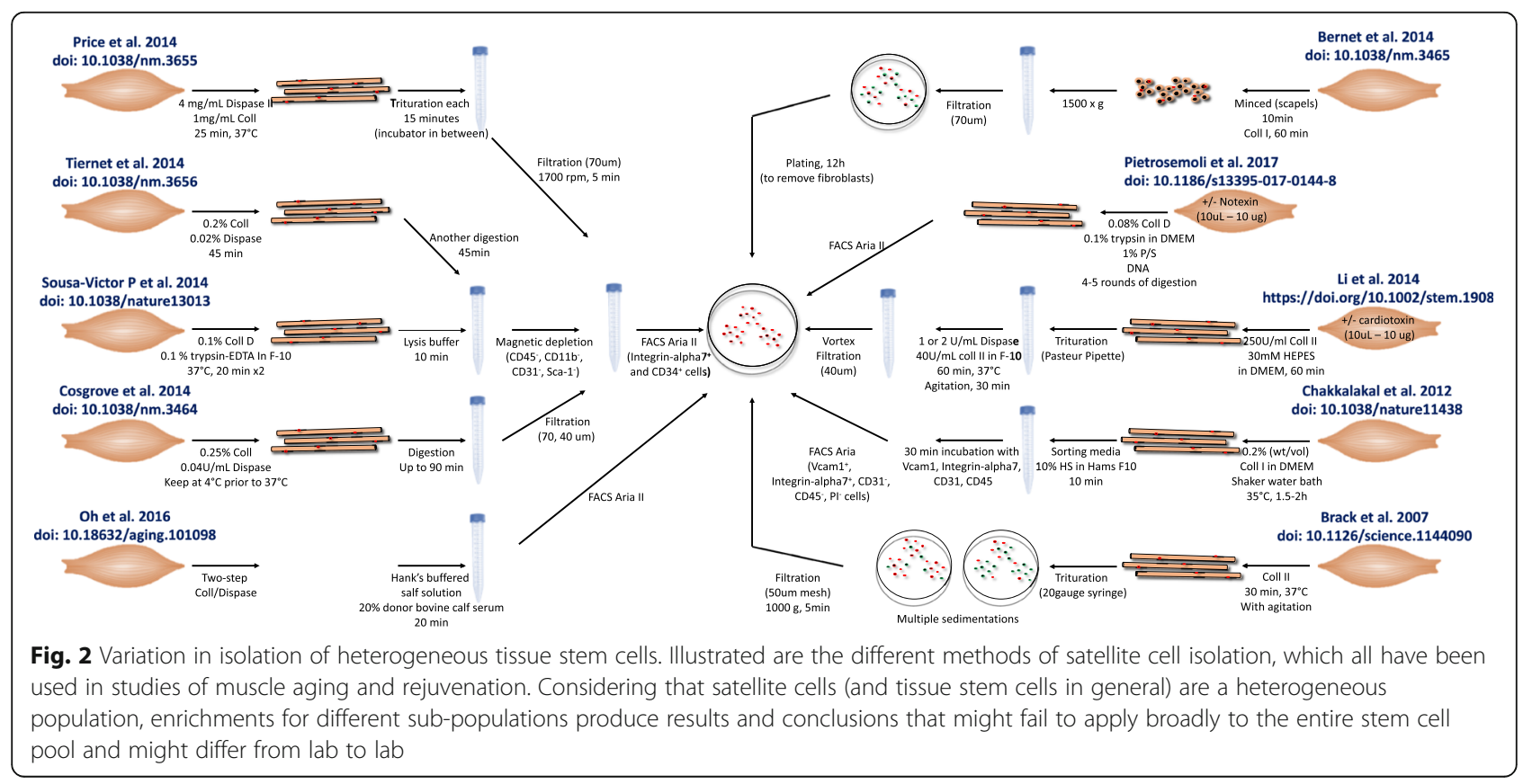


that are in deeper state of quiescence [89]. The number of SCs varies by muscle types, and overall declines with age [90-95], although whether this decline is slight or severe is a matter of some debate [10, 14, 51, 52, 96-98]. The hindlimb muscles of newborn and juvenile rodents contain a mix of SCs and their more differentiated progeny: proliferating myoblasts that are numerous, summing to around $30 \%$ of total sublaminar myonuclei, and supporting the rapid growth of juvenile muscle. When a more quiescent adult stem cell pool is established in 2month-old mice [99-101], the SCs represent less than $5 \%$ of myofiber sublaminar nuclei and remain relatively constant in adulthood. Adult muscle is hence composed of postmitotic multinucleated myofibers and their associated non-dividing, quiescent SCs. By a geriatric 30 months of age, SCs represent $2.5 \%$ of the total muscle cells $[71,102,103]$. Yet this decline is not drastic compared to adult or old mice when normalized to muscle mass, which has also declined by such an advanced age $[10,14,51]$. Another important variable to account for when determining the number of SCs is the muscle type. Generally, adult slow-twitch myofibers (type I) such as that predominate in the soleus are generally associated with two- to fourfold higher SC numbers than fasttwitch, type IIa and IIb myofibers that predominate in the tibialis anterior or EDL [104].

SCs are critically needed for the regeneration of injured muscle fibers and, to a small extent, they participate in the process of overload hypertrophy, for example when muscle fibers grow through protein synthesis and become bigger there might be some SC proliferation to populate the enlarged fiber mass [105-107]. Conversely, muscle fibrosis and atrophy can be induced by SC depletion [108111]. Cellular homeostasis is tightly regulated in muscle, as evidenced from the restoration of sufficient quiescent SCs after a local tissue injury, to support future needs of repair $[112,113]$. Rather than a significant decline in the total number with age, most of the data support a dramatic lack of activation of muscle stem cells after injury and a concomitant lack in the formation of progenitors that are needed for repair $[7,8,114,115]$. This lack of myogenic cells is in part due to reduced asymmetric divisions among myogenic stem and progenitor cells and is also linked to diminished SC self-renewal [53, 116-118].

\section{Age-specific changes in key signaling pathways}

Signaling pathways play essential roles in SC maintenance and adult myogenesis, which largely recapitulates the cellular and molecular regulations that take place during embryonic myogenesis. Notch signaling plays a critical role by regulating the quiescence and proliferation decisions of SCs, in cooperation with syndecan3, and in influencing asymmetric cell division through antagonism with the Wnt/beta-catenin signaling. Notably, the age-specific role of Notch and Wnt interplay, as well as that of the TGF-beta, Jak/Stat, etc. pathways that was deciphered in muscle, is conserved in the brain, blood, bone, gut, and other tissues [119-122].

The Notch ligand Delta1 is upregulated by damaged myofibers and provides the temporal and positional cues for Notch activation in quiescent SCs [7, 49, 51]. Notch signaling promotes myoblast proliferation and inhibits their differentiation $[49,51,123-126]$ in part through antagonism with Wnt signaling [50]. Notch also contributes to return of Pax7+MyoD- cells to quiescence [127]. Muscle regeneration relies on the tight balance between self-renewal and myogenic commitment. With age, SCs undergo excessive commitment and precocious differentiation [52], revealing a dysfunction in the ability to undergo proper asymmetric division. Delta expression and hence Notch activation is lacking in aged SCs; thus, very few SCs break quiescence or engage in tissue repair [51]. In addition, aged SCs progressively express a high level of JAK/STAT signaling targets $[53,118]$, have elevated TGFbeta/pSmad2,3 [10], and perturbed p38 signaling [116, $117,128-131$ ], all of which promote myogenic differentiation at the expense of SC self-renewal and myoblast expansion. Similarly, the Wnt/beta-catenin pathway promotes the formation of fusion-competent myoblasts and myotubes, but also inhibiting the expansion of SCs when Wnt becomes excessive with age $[8,50]$.

\section{Tissue rejuvenation}

Muscle has served as an excellent model for assessing tissue rejuvenation because it undergoes clear-cut and welldescribed physiological, histological cellular and molecular changes with age. The summary of approaches for muscle rejuvenation is outlined in Fig. 3. In addition, adult myogenesis takes place throughout mammalian life and is wellcharacterized. At the beginning of muscle regeneration soon after the injury, small diameter myofibers with centrally located myonuclei are produced by the fusion of myoblasts. They can be distinguished histologically by morphology and expression of the embryonic/developmental isoforms of myosin heavy chain (eMyHC). With time (weeks), these myofibers increase in size and the myonuclei migrate to the periphery, so that regenerated muscles appear indistinguishable from undamaged muscles. A hallmark of the aging muscle is a decline in the formation of eMyHC+ myofibers after injury, persistence of inflammatory cells and cytokines, and expansion of fibrosis [132, 133].

An alternative method of assaying aging and rejuvenation consists of measuring the size of the new myofibers that repaired the injury, assuming that bigger myofibers are better. However, if the injury is successfully repaired by small muscle myofibers, there could have been prolonged myogenic proliferation at the expense of fusion or 


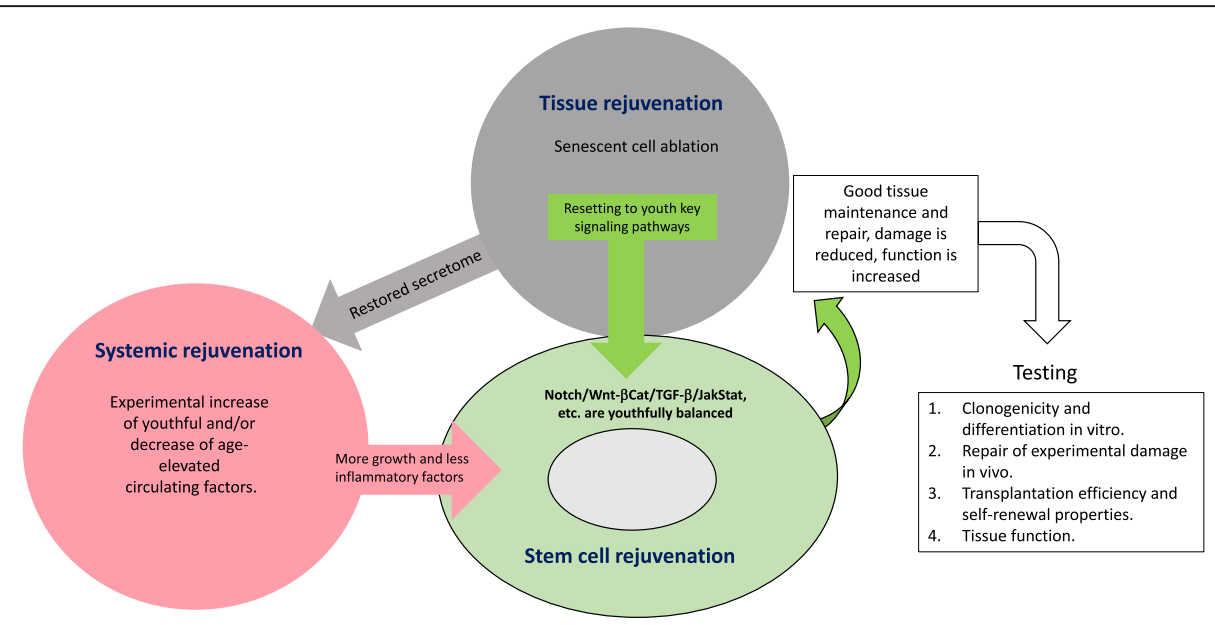

Fig. 3 Summary of the approaches for tissue, systemic and stem cell rejuvenation. Multiple experimental approaches have been used (typically, in mice) for tissue rejuvenation and/or systemic rejuvenation; these include ablation of senescent cells and re-calibration of key signaling pathways that are needed for productive stem cell responses. To test the success in experimental rejuvenation, 1-4 approaches are typically applied, and skeletal muscle is well-suited for assaying each one, as described in the text

differentiation, and most myofibers eventually increase their size by fusing with each other and/or through protein synthesis and hypertrophy. The early time points after injury (5-7 days) serve best for assaying eMYHC+ centrally nucleated myofibers, for after 2 weeks, eMyHC expression is lost and regenerated myofibers begin to look similar to non-injured ones. However, for assaying the age-specific changes in muscle physiology and function, contractility, and strength, longer time points (2-4 weeks) are clearly preferable $[52,134]$.

The myogenic capacity of freshly isolated SCs can also be assayed in vitro by measuring the numbers of myoblast clusters that are produced in hours to days after derivation from the muscle and by the numbers and multi-nuclearity of myotubes that differentiate from those isolated myoblasts. In such assays, young SCs or myofibers with their associated SCs are typically more myogenic than their old counterparts. The age-specific changes in the clonogenic capacity have been studied in the muscle and are typical for other tissues such as hematopoietic, liver, bone, brain hippocampus, and skin, underscoring the significance of muscle as a superb experimental system in aging research. Linked to the clonogenic capacity and also generally shared by stem cells from different tissues is the age-specific transplantation efficiency of SCs [53, 62, 77, 95, 117, 135-140]. Interestingly, early muscle transplantation studies suggest that the age of the host rather than the age of the SCs seem to influence the success in regeneration [141].

Studying the above-described parameters in young, old, and experimentally rejuvenated muscle yielded a number of novel paradigms that broadly apply to tissue aging and rejuvenation [41, 42]. For example, experiments that allow sharing young donor constituents (blood, secreted molecules, and organs), with an old host, were shown to rejuvenate myogenicity and to restore the youthful Delta/Notch signaling after injury $[8$, 14, 142-144], but also rejuvenate the brain, cognition, liver, skin, bone, etc. Clinically relevant attempts to rejuvenate the circulatory niche of muscle stem cells include neutralization of Wnt and TGF- $\beta$ in old mice by inhibiting the age-elevated ligand molecules and/or their signaling pathways [93, 145, 146]. Activation of FGF2-p38alpha/ beta MAPK, ectopic oxytocin/MAPK, interleukin33 (IL33) supplementation, or IL6-JAK/STAT3 pathways, e.g., the determinants which decline with age, have also been shown to rejuvenate myogenic responses [147]. In a dualprong approach, oxytocin (a signaling peptide that declines with age) was combined with a low dose of an inhibitor of TGF-beta/pSmad (signaling that increases with age). Emphasizing cross-tissue conservation of ageassociated changes, this defined pharmacology not only enhanced muscle repair but also improved cognitive function through a probable reduction of neuroinflammation and reduced liver adiposity and fibrosis in old mice [148]. GDF11, once suggested as pro-regenerative youthful factor [142], was found to actually inhibit muscle regeneration [149] possibly through SCs inhibition [145]. The inhibitory role of GDF11 is consistent with the phenotypes of GDF11 gene knockout mice $[146,150]$ and the fact that this TGF- $\beta$ family member activates pSmad 2, 3 signaling, which is already elevated in the old and well known to block cell proliferation in general and specifically of SCs $[147,149,151])$. A protein very similar to GDF11, myostatin (aka, GDF8) has a known inhibitory role for SCs proliferation and muscle growth; accordingly, its antagonist follistatin is pro-regenerative [152-154]. Like other TGF- $\beta$ family proteins, GDF11 is pro-angiogenic and it might 
support muscle regeneration through increased blood vessel formation, albeit at risk of promoting oncogenesis, as GDF11 has a high association with human cancers [155-158].

\section{The age-associated biophysical and biochemical changes in the stem cell niche}

The general directions of experimental rejuvenation are based on the fact that maintenance and repair of mammalian tissues is regulated by systemic and local cell signaling molecules [41, 42]. Skeletal muscle is a good example of the multi-level endocrine and local tissue control of homeostatic maintenance and regeneration. Muscle is highly vascularized, and the molecular composition of the systemic milieu has a profound influence on the maintenance and repair of this tissue. Heterochronic parabiosis and blood exchange (apheresis) studies uncovered the phenomenon of rapid restoration of regeneration in old muscle, through exposure to a young organism (in parabiosis) or just young blood (apheresis). These experiments pointed out the crucial age-specific roles for the SC niche, of interstitial cells, blood vessels, extracellular matrix proteins with their storage of secreted factors, as well as the systemic environment (circulation) for both the maintenance of SCs in the quiescent state and their activation for proliferation, differentiation, and tissue repair. In confirmation of the multi-tissue conservation of the paradigms uncovered in aged muscle, rejuvenation of the CNS, brain, bone, kidneys, liver, etc. have also been demonstrated through blood heterochronicity [41, 42]. Moreover, many key age-specific biophysical and biochemical changes that were established through studies of muscle apply more generally to these other tissues and clarify the overall ageimposed increases in fibrosis and inflammation.

Through its components (fibrillar proteins, growth factors, glycoproteins, chemokines, cytokines), the extracellular matrix (ECM) presents the biochemical and biophysical cues that home the SCs to specific locations of the myofiber and control the cell-intrinsic polarity and cell-fate decisions, which are essential for SC functionality [127, 159-161]. Laminin, the primary protein of the ECM, along with other glycoproteins such as type IV collagen, perlecan, entactin (nidogen), and fibronectin, support SCs proliferation [128-130, 162]. Proteoglycans act as receptors for precursor forms of growth factors (HGF, bFGF, EGF, IGF-I, IGF-II), which are required for activation of SCs in response to muscle damage [163, 164]. In return, SCs express the integrin receptors that interact with the basal lamina to regulate appropriate ECM deposition from fibroblasts and to prevent fibrosis [110, 165]. With age, muscle displays lower levels of elastin and fibronectin, which are cleaved and increasingly accumulate in the surrounding connective tissue, leading to compromised muscle maintenance and degradation of the ECM through tissue necrosis [166]. The age-imposed misprocessing of ECM proteins leads to the accumulation of toxic-byproducts and altered properties of the basal lamina. Compromised interaction with the ECM also leads to weaker adhesion of SCs to their associated myofibers, and detachment or a perception of detachment leads to a programmed cell death called anoikis [130].

ECM integrity and remodeling depends on the dynamic balance between remodeling enzymes (matrix metalloproteinases, MMPs) and their inhibitors (tissue inhibitors of metalloproteinases, TIMPs) $[167,168]$. During muscle regeneration, MMP2 secreted by SCs and MMP9 produced by IL6 secreting leukocytes [169] degrade type IV collagen, among other constituents of the ECM, thereby allowing recruitment of activated SCs to the site of muscle injury [170]. In addition, MMP-9 converts the matrixtethered latent TGF- $\beta$ complex to an active form [171] and subsequently stimulates matrix deposition [172]. The persistent inflammation associated with aging leads to alterations in the composition of the ECM, where atypical types of collagen are seen along with a shift toward collagen IV and reduced collagen VI [173, 174]). The aged ECM retains fewer glycoproteins and is characterized by infiltration of adipose and fibrotic tissues $[8,87]$. Together, these age-imposed processes ultimately drive an increase in fibrosis and matrix rigidity, increasing the elastic modulus to $\sim 418 \mathrm{kPa}$ instead of the productive $\sim 12 \mathrm{kPa}$ of the young muscle [72]. Aged single myofibers also have an increased physical stiffness that correlates with the increased crosslinking of their collagens $[175,176]$, and when cultured on hydrogels that mimic this stiffness, adult primary myoblasts show increased differentiation at the expense of proliferation [175]. The deposition of extra basal lamina into the SC-myofiber interspace interferes with the intimate association between SC and their myofibers [103]. This expulsion from the niche changes multiple molecular cues that regulate the asymmetry of SC divisions and their cellfate, and it might cause the disparity in young versus old $\mathrm{SC}$ cell counts between bulk fiber preparations as opposed to single fiber studies [8]. In addition, with age, the ability of the ECM to function as a reservoir for growth factors and their conversion to active forms become altered [174]. Age-imposed changes in the ECM composition perturb regeneration through inadequate support of muscle fibers and disorganized scaffold orientation [177-179]. The $\mathrm{p} 38 \alpha / \beta$ MAPK axis was shown to play an essential role in muscle mechanobiology [117, $130]$, and age-imposed changes in muscle tensegrity contribute to the impaired function of SCs $[149,175$, $176,180]$. The main age-specific changes in muscle ECM are depicted in Fig. 4.

In concert with the studies in muscle, work with other cell types (including mammary epithelial, fibroblasts and mesenchymal stem cells) indicates significance of age- 


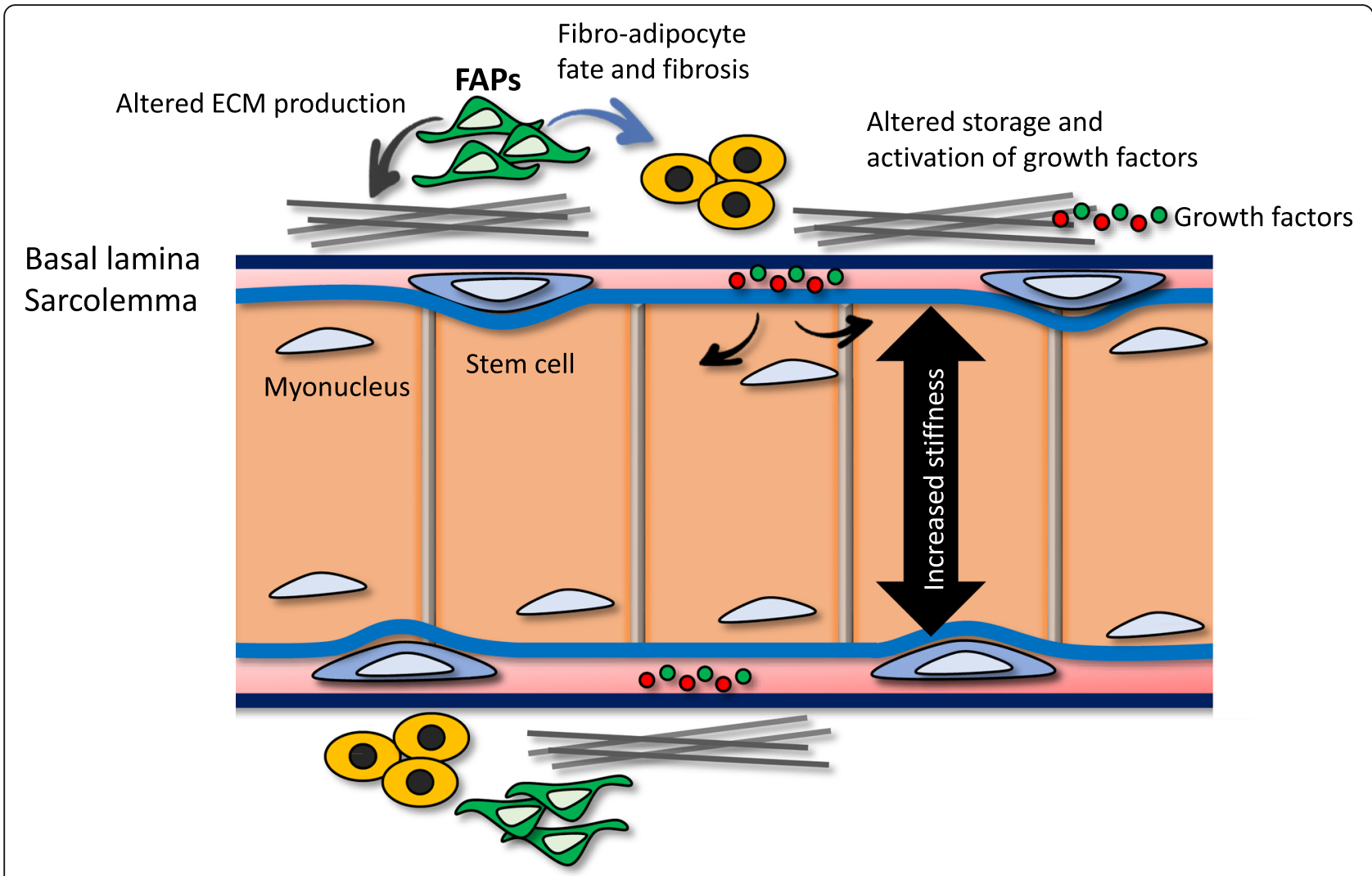

Fig. 4 Connection between biochemical and biophysical age-associated tissue changes are exemplified in skeletal muscle. With age, composition of ECM becomes altered through changes in FAPs, persistent damage, fibrosis, and inflammation; these age-associated changes make myofibers stiffer and diminish the capacity of ECM for proper storage and activation of growth factors

specific changes in ECM for loss of stem cell properties and accumulation of senescent cells and suggests that interactions between integrin-focal adhesion complexes and the actin-myosin network broadly help cells to sense matrix elasticity, which in turn influences cell behavior and fate [181-186].

\section{Age-specific changes in the epigenome}

The environment largely influences the epigenomic program (i.e., post-translational modifications), which determines the fate of activated adult stem cells through the expression or repression of specific genes. Studies of muscle have greatly contributed to the broad understanding of ageassociated epigenetic changes in stem cells. Namely, the changes that were observed between young versus old SCs and were correlated with the global transcriptome of these stem cells $[53,116,187]$ have been extrapolated to other tissues and their stem cells, such as hematopoietic [188], heart [188], and brain [188, 189].

Notch signaling might contribute to the age-imposed changes in the SC epigenome through positive regulation of Bmi1 [96, 190, 191], a component of the polycomb repressive complex 1 (PRC1), in coordination with enhancer of zeste homolog 2 (Ezh2), a component of PRC2.
Together, they repress the expression of several genes such as $\mathrm{p} 16^{\mathrm{INK} 4 \mathrm{a}}$ through maintenance of H3K27me3 marks [192, 193]. With age, the redistribution of PRC1 and PRC2 may activate SCs and inhibit their self-renewal, driving a cellular senescence phenotype associated with aged SCs [194-197]. Evidence of this pathway comes from the observation that deletion of Bmil in young SCs prevents their active participation in muscle regeneration [197]. Similarly, elevated with age TGF-beta and diminished MAPK signaling activate the expression of CDK inhibitors and promote cell cycle arrest in muscle SCs and in neural precursor cells $[10,84,198]$.

Some studies on epigenetic and transcriptional profiling in SCs suggest that the overall permissive state (e.g., H3K4me3) is age unrelated. However, the dominant and repressive marks (e.g., H3K27me3) accumulate and spread with age [187], probably reflecting the decrease in proliferative capacity and the inability of SC to self-renew as these repressive epigenetic marks are transmitted to daughter cells [194-197]. An age-imposed loss of epigenetic inactivation of CDK inhibitors loci takes place in SCs, resulting in permissiveness of CDK expression and a lack of myogenic proliferation [84, 96]. Aged activated SCs also display an altered epigenetic stress response [199]. Interestingly, 
the experimental activation of FGF2/MAPK reverses the age-imposed epigenetic anti-proliferative signature to a younger, closed chromatin state [84, 200].

In this regard, there is an observation of a very slow and gradual SC exhaustion though proliferation that might be relevant for old people, particularly those who constantly damage muscle by extremely rigorous exercise [93, 201]. However, in mice, virtually, no SCs incorporate BrdU in uninjured muscle and are mitotically quiescent in the young ( 2 months or older) or the old animals $[62,202,203]$. Nevertheless, even in the absence of $\mathrm{SC}$ exhaustion, mouse muscle ages (much faster than that of humans) with pronounced lack of SC responses and sarcopenia. Moreover, all examined CDK inhibitors (p15, p16, p21, p27) become elevated in aged SCs, as compared to young, and there is an age-imposed epigenetic permissiveness of the $\mathrm{p} 16^{\mathrm{INK} 4 \mathrm{a}}$ and $\mathrm{p} 21^{\mathrm{CIP} 1}$ loci in old SCs after injury [84]. With age, there is a loss of the PRC1-mediated repressive H2A-lysine 119 ubiquitination mark, which leads to de-repression of the $\mathrm{p} 16^{\text {INK4a }}$ locus and SC inactivation, a loss of myogenic fate (absence of $\mathrm{MyoD}$ ), and the acquisition of a senescent cell fate that is marked by elevated gamma-H2A histone family member $\mathrm{X}(\gamma \mathrm{H} 2 \mathrm{AX})$ foci and secretion of the "senescence-associated secretory phenotype" [96].

Generally speaking, the lack of activation versus too much activation (e.g., proliferative exhaustion are the general paradigms under investigation in the broad area of tissue stem cell aging) and the understanding of these phenomena in muscle resonates well with the work in the gut, skin, blood, and brain [119, 204-208].

\section{Inflammation}

As true in other tissues that undergo life-long remodeling (gut, bone, blood, liver, skin, etc. [209-211]), muscle regeneration and inflammation coincide in space and time [212]. The study of muscle provided insights into the process of the age-specific decline in tissue maintenance and the dominance of inflammation. To some degree, inflammation is useful for tissue repair: the inflammatory response, mostly by myeloid cells, removes the degenerating debris, and the temporary scar allows the correct orientation and deposition of new ECM by muscle-resident fibroblasts, which also provide prodifferentiation signals to myoblasts. Some inflammatory cytokines and myokines are produced and promote myogenesis, activate endothelial cells for angiogenesis, and attract new nerve projections [88, 213-217].

Numerous immune cells infiltrate damaged muscle, with neutrophils being the first responders to the injured site at 1-6 h. These secrete pro-inflammatory molecules such as cytokines (TNF-alpha, IL6), chemokines (CCL2 and 17), and growth factors (FGF, HGF, IGF1; VEGF, TNF-beta) that create a chemo-attractive environment to monocytes and macrophages. M1 phagocytic CD68+/ CD163- macrophages arrive at 2 days post-injury and are replaced by M2 non-phagocytic CD68-/CD163+ macrophages at 4 days post-injury [218, 219]. This switch in the macrophage populations has been described as critical for stopping inflammation and enabling both the differentiation and fusion of myoblasts [220, 221]. With aging, the M1 profile dominates over M2 during muscle repair [222, 223], which is in part due to the elevation of macrophageproduced osteopontin, which in turn induces a battery of inflammatory cytokines that inhibit myogenesis [87] and phagocytic activity. The M1 to M2 switch that was found in studies of skeletal muscle is a general trend with aging and is responsible to diminished repair and increased chronic inflammation in the joints, lung, liver, the gastrointestinal track, and other tissues. Recently, another class of immune cells, $\mathrm{T}$ regulatory cells (Tregs), has gained interest due to their ability to dampen the inflammatory response and promote tissue repair [224] in the muscle, heart, skin, kidney, and brain [225-229]. In aged muscle, the lack of local secretion of IL33, probably by the fibro-adipogenic progenitor (FAP)-like cells (the major source of this inflammatory cytokine), impairs the attraction of Tregs to the injury site, and results in a decline of regenerative capacity [230].

Age-elevated inflammation negatively impacts not only SCs [112-114], but also other cell types, mostly stromal cells, such as blood vessel associated mesoangioblasts, mesenchymal stem cells, FAPs, ALDH+/CD34- cells, CD133+ cells, and pericytes [231-238]. Most of these have been studied in age-comparative ways in muscle [239241] and are clearly important for most mammalian tissues. Of particular interest, FAPs constitute a nonmyogenic population essential for muscle regeneration. Undifferentiated quiescent FAPs in the interstitium of healthy young muscle have positive effects on SCs activation and the proliferation of myoblasts, potentially via secretion of IL6, IGF1, Wnt1, Wnt3a, and Wnt5a [238, 242]. However, excessive activation of FAPs following injury in aged muscle induces their differentiation into adipocytes and into the myofibroblasts that are the main secretors of type I collagen and contribute to progressive fibrosis. Fibrosis is further promoted in old muscle through activation of adipocytes when eosinophil production of IL4 declines [243], and the cytokine profile of macrophages becomes pro-inflammatory [244].

\section{Selecting a specific sample size in studies of aging}

Considering recent focus on scientific rigor and the large variety of approaches in muscle aging research, this review will end with a section on one key scientific parametersample size-providing out perspective on choosing the optimal numbers of experimental animals. Researchers investigating aging and rejuvenation of muscle and other tissues typically experiment on 5-6 male mice per cohort, 
and historically, these numbers yielded statistically relevant, robust data $[7,8,51,115]$. However, some report as many as $10-15$ animals per cohort $[109,142]$. So how many animals are really needed?

The size and the composition of the cohorts are crucial as they determine the relevance of the observed effects, while attempting to comply with ethical considerations and limitation in the use of resources. The National Research Council's Guide for the Care and Use of Laboratory Animals guidelines state that the number of live animals used for research should be minimized. The tenets of ethical animal use are described as "the three R's": replacement, refinement, and reduction [245]. The reduction principle aims to maximize the amount of data collected from the fewest number of animals practical.

Due to the law of diminishing returns [246], having an unnecessarily large sample size results in negligible gains in statistical significance that do not justify extra costs, animals, or time. Inversely, selecting too small a sample size runs the risk of the experiment having inadequate power for detecting significant effects, which also renders the financial, animal, and time resources wasted [246-250]. Ideally, the sample size should be sufficiently large to provide the experiment with adequate statistical power, while at the same time minimizing the number of animals needed to achieve statistically significant results. The method used for accurate determination of the sample size primarily depends on whether there are existing data to inform a prediction of the treatment effect size, ES, and the population standard deviation, $\sigma$. Statistical power analysis is the most robust method for determining sample size, and it is used whenever at least some population statistics are available. When no prior statistics are available to do a power analysis, a pilot study is done using a resource equation to determine the number of animals needed to detect any effect of an exploratory condition. This scenario could be minimized by searching the literature for population data that could be used for a power analysis. The key aspects of the power analysis and resource equation are briefly outlined below.

Generally speaking, when a normally distributed population mean and standard deviation can be reasonably estimated, and it can be assumed that the experimental data will be normally distributed, then statistical power analysis is used to determine the minimum number of animals $n$ per cohort. In such analysis, the null hypothesis $H_{0}$ and the alternative hypothesis $H_{A}$ are defined as follows:

$$
\begin{aligned}
& H_{0}: \bar{X}=\mu \\
& H_{A}: \bar{X} \neq \mu
\end{aligned}
$$

where $\mu$ is the presumed population mean, and $\bar{X}$ is the sample mean. Rejecting the null hypothesis when the sample mean is not different from the population mean results in a type I error and occurs with probability $\alpha$. Failing to reject the null hypothesis when the sample mean truly differs from the population mean results in a type II error and happens with probability $\beta$. This is summarized [247] and depicted in Table 1.

The power of a hypothesis test is the probability of rejecting $H_{0}$ when it is indeed false. This is simply the complementary probability to $\beta$ or making a type II error:

$$
\text { Power }=1-\beta
$$

The probability $\beta$, and therefore the power, depends on $\alpha$, the sidedness of the test (one-tailed or two-tailed), the effect size ES of the treatment, $\sigma$, and the sample size $n$. From this relationship, one solves for the minimum $n$ needed to detect a desired ES with a test having a desired confidence level and statistical power. The interplay between ES, $\alpha, \beta$ and other parameters is visualized in Fig. 5 [247-251].

In general, as the desired confidence level for the test increases, the probability of a type I error decreases, but at the expense of power. Decreases in power and/or confidence can be mitigated by a tight distribution of the data (low $\sigma$ ), a large ES, or by increasing $n$ (which has the effect of lowering $\sigma$ ). However, in adhering to the reduction principle, $n$ should be minimized by some combination of decreasing our confidence, decreasing the power, or increasing the minimum ES detectable by the test. Typical acceptable values for $\alpha$ are 0.05 or lower, and typical values for power are 0.8 or 0.9 .

There are numerous online calculators to determine sample size such as:

https://www.stat.ubc.ca/ rollin/stats/ssize/n2.html https://www2.ccrb.cuhk.edu.hk/stat/mean/osm_equivalence.htm

Finally, to ensure the success of the experiment, the researcher must account for the expected attrition rate $A$ (in particular working with old mice, some may die from "old age" during the experiment) and calculate the corrected sample size $n^{\prime}$ [11]:

$$
n^{\prime}=\frac{n}{1-A}
$$

For exploratory treatments where there is no reliable a priori knowledge to inform about the effect size or standard deviation, a power analysis to determine sample size is not feasible. A pilot study can be done, not to measure actual effect size, but rather to determine if

Table 1 Outcome space of a hypothesis test

\begin{tabular}{lll}
\hline & $\bar{X}=\mu$ & $\bar{X} \neq \mu$ \\
\hline Reject $H_{0}$ & Type I error & Correct conclusion \\
Accept $H_{0}$ & Correct conclusion & Type II error \\
\hline
\end{tabular}




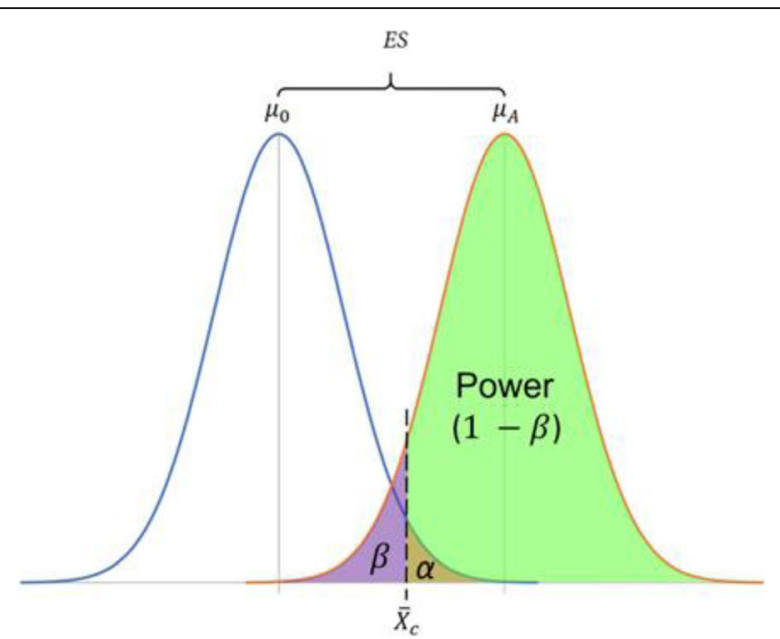

Fig. 5 The relationship between $E S, a, \beta$, and power for a one-tailed test where it is expected that $\mu_{A}>\mu_{0}$. The critical value $\bar{X}_{C}$ is the minimum sample mean to needed to reject $H_{0}$ at the desired confidence level (1 $-a$ ). Note that for a given $\alpha$ and $E S$, the area of $\beta$ increases and the power decreases with increasing variability in the distributions. Conversely, if variability decreases, the power increases and $\beta$ decreases

there is any detectable difference between control and experimental groups. To adhere to the reduction principle, the number of animals should still be minimized in pilot studies, but a sufficiently large sample size is also needed for adequate detection power. A resource equation can be used to infer the smallest sample size that is nevertheless adequate to detect variability between groups [249-253].

An experiment with sample size $N$ testing for the effects of a treatment can have at most $N-1$ degrees of freedom (df) or points allowing for variability [252]. The resource equation breaks this variability into three components: blocking $B=b-1$, treatment $T=t-1$, and error $E$ dfs. Blocking refers to the separation of cohorts into $b$ groups based on environmental factors (or, sex, age, etc.). $T$ refers to the number of questions $t$ being asked. $E$ is used as an estimation of the variance within treatment groups. The total $(N-1) \mathrm{df}$ is equal to the sum of the dfs of the three variability components:

$$
B+T+E=N-1
$$

For a good estimate of the variance, $E$ must be greater than 10 , but for values greater than 20 , there is a negligible gain in statistical significance which would not justify the increased number animals. With that in mind, it is up to the researcher to decide on the value of $E$ when solving for $N$.

Using higher numbers of animals than those suggested by the above resource equation or power analysis have been concluded not to yield better or more reliable data, and indeed, high sample numbers did not overcome conflicting results in comparative body of published work on GDF11 and pSMAD signaling and aging. In our experience, if a small number of animals per cohort do not show a robust difference between experimental and control groups, then perhaps the researcher should consider a more robust experimental assay or a different experimental approach to answer the question. We also find multiple experimental approaches, each with smaller cohorts, to answer the same general question to be a more rewarding use of time and resources. For example, two experiments, one examining the effects of modulating a ligand and another modulating the receptor or downstream signaling, will give either corroborating or conflicting results, and that depends more on whether the phenomenon is robust or not and less on how many animals were used in the assays. Finally, the bulk of studies on muscle aging and rejuvenation are mostly if not only from male mice that, moreover, are genetically identical and environmentally similar. Therefore, the magnitude of effects and robustness should be interpreted with caution as they may not translate exactly to clinical studies [254].

\section{Conclusion}

In recent decades, the health and regeneration of skeletal muscle have been frequently used as key experimental systems in studies that focused on understanding and reversing mammalian tissue aging. This body of work enriched the field of adult myogenesis, the broader arena of aging research, and yielded advances in stem cell isolation and characterization, pathway reconstruction, omics, etc. biomedical approaches. The field of muscle research in general and in application to aging is still burgeoning as revealed by innovative technologies and exemplified by in situ single-cell cartography, the high definition comprehensive mapping of muscle resident types [255]. Aging research in muscle is multidisciplinary, and it cross-pollinates different fields of science, including stem cell biology and regenerative medicine, bioengineering and mechanobiology, Big Data, omics, and imaging. Such diversity of technologies and approaches enables robust and rigorous checks and validations of the findings by the body of published work in this clinically relevant field of science, ultimately yielding feasible therapies for extending productive health span.

\section{Abbreviations}

ALDH: Aldehyde dehydrogenases; bFGF: Fibroblast growth factor-basic; BrdU: Bromodeoxyuridine; CCL2/17: Chemokine ligand 2/17; CD 33/45/68/ 163: Cluster of differentiation 33/45/68/163; CDKIs: Cyclin-dependent kinase inhibitor protein; C-Met: Tyrosine-protein kinase Met; CNS: Central nervous system; Coll: Collagenase; CXCR4: C-X-C chemokine receptor type 4; Df: Degree of freedom; DMEM: Dulbecco's modified Eagle medium; DNA: Deoxyribonucleic acid; ECM: Extracellular matrix; EDL: Extensor digitorum longus; EGF: Epidermal growth factor; eMYHC: Embryonic myosin heavy chain; Ezh2: Enhancer of zeste homolog 2; F-10: Ham's F-10 Nutrient Mixture; FACS: Fluorescence-activated cell sorting; FAPs: Fibro-adipogenic 
progenitors; FBS: Fetal bovine serum; FGF: Fibroblast growth factors; GammaH2AX or $\gamma H 2 A X:$ Gamma-H2A histone family member X; GDF8/11: Growth differentiation factor 8/11; H3K27me3: Tri-methylation at the 27th lysine residue of the histone $\mathrm{H3}$ protein; $\mathrm{H} 3 \mathrm{~K} 4 \mathrm{me}$ : Tri-methylation at the 4th lysine residue of the histone H3 protein; HGF: Hepatocyte growth factor; IGF1: Insulin-like growth factor 1; IL4/6/33: Interleukin 4/6/33; ITGB1: Integrin beta 1; JAK: Janus kinase; kPA: Kilo pascal; M1/2: Macrophage type M1/M2; MAPK: Mitogen-activated protein kinase; microRNA: Microribonucleic acid; MMP: Matrix metalloproteinases; Myf5: Myogenic factor 5; MyoD: Myoblast determination protein 1; NCAM: Neural cell adhesion molecule; p15: Cyclindependent kinase 4 inhibitor B (CDKN2B); p16 ${ }^{\text {INK4a }}$ : Cyclin-dependent kinase inhibitor 2A (CDKN2A); p21 ${ }^{\mathrm{Cip} 1}$ : Cyclin-dependent kinase inhibitor 1 (CDKN1A); p27: Cyclin-dependent kinase inhibitor 1B (CDKN1B); Pax3/ 7: Paired box gene 3/7; PRC1/2: Polycomb repressive complex 1/2; ROS: Reactive oxygen species; SC: Satellite cells; Sca1: Stem cells antigen 1; STAT3: Signal transducer and activator of transcription 3; TGFbeta: Transforming growth factor beta;; TIMPs: Tissue inhibitors of metalloproteinases; TNF-beta: Tumor necrosis factor-beta; Tregs: Regulatory T cells; VCAM: Vascular cell adhesion protein 1; VEGF: Vascular endothelial growth factor; WNT1/3a/5a: Wingless-related integration site1/3a/5a

\section{Acknowledgements}

Not applicable.

\section{Authors' contributions}

All authors contributed to some extent to the writing and the editing of the manuscript and figure design. All authors read and approved the final manuscript.

\section{Funding}

NHLBI RO1, NIBIB RO1, and Open Philanthropy grants to IC.

\section{Availability of data and materials}

Not applicable

\section{Ethics approval and consent to participate}

Not applicable

\section{Consent for publication}

Not applicable

\section{Competing interests}

The authors declare that they have no competing interests.

\section{Received: 6 August 2019 Accepted: 12 January 2020}

Published online: 07 February 2020

\section{References}

1. Toh WS, Brittberg M, Farr J, Foldager CB, Gomoll AH, Hui JHP, et al. Cellular senescence in aging and osteoarthritis. Acta Orthop. 2016;87:6-14.

2. Milholland B, Suh $Y$, Vijg J. Mutation and catastrophe in the aging genome. Exp Gerontol. 2017;94:34-40.

3. Austad SN, Hoffman JM. Is antagonistic pleiotropy ubiquitous in aging biology? Evol Med Public Health. 2018;2018:287-94.

4. van den Heuvel J, English S, Uller T. Disposable soma theory and the evolution of maternal effects on ageing. PLoS One. 2016;11:e0145544 [Cited 2019 May 31] Available from: https://www.ncbi.nlm.nih.gov/pmc/articles/ PMC4709080/.

5. Kaushik S, Cuervo AM. Proteostasis and aging. Nat Med. 2015;21:1406-15.

6. Blackburn EH, Epel ES, Lin J. Human telomere biology: a contributory and interactive factor in aging, disease risks, and protection. Science. 2015;350:1193-8.

7. Conboy IM, Conboy MJ, Wagers AJ, Girma ER, Weissman IL, Rando TA. Rejuvenation of aged progenitor cells by exposure to a young systemic environment. Nature. 2005;433:760-4.

8. Brack AS, Conboy MJ, Roy S, Lee M, Kuo CJ, Keller C, et al. Increased Wnt signaling during aging alters muscle stem cell fate and increases fibrosis Science. 2007:317:807-10.

9. Villeda SA, Luo J, Mosher Kl, Zou B, Britschgi M, Bieri G, et al. The ageing systemic milieu negatively regulates neurogenesis and cognitive function. Nature. 2011:477:90-4.

10. Conboy IM, Conboy MJ, Rebo J. Systemic problems: a perspective on stem cell aging and rejuvenation. Aging (Albany NY). 2015;7:754-65.
11. Conboy IM, Rando TA. Heterochronic parabiosis for the study of the effects of aging on stem cells and their niches. Cell Cycle. 2012;11:2260-7.

12. Navarrete-Reyes AP, Soto-Pérez-de-Celis E, Hurria A. Cancer and aging: a complex biological association. Rev Investig Clin. 2016:68:17-24.

13. López-Otín C, Blasco MA, Partridge L, Serrano M, Kroemer G. The hallmarks of aging. Cell. 2013;153:1194-217.

14. Conboy IM, Rando TA. Aging, stem cells and tissue regeneration: lessons from muscle. Cell Cycle. 2005;4:407-10.

15. Hardeland R. Aging, melatonin, and the pro- and anti-inflammatory networks. Int J Mol Sci. 2019;20:1223.

16. Sadighi Akha AA. Aging and the immune system: an overview. J Immunol Methods. 2018;463:21-6.

17. Erickson MA, Banks WA. Age-associated changes in the immune system and blood ${ }^{-}$brain barrier functions. Int J Mol Sci. 2019;20:1632.

18. Fougère $B$, Boulanger $E$, Nourhashémi F, Guyonnet $S$, Cesari M. Chronic inflammation: accelerator of biological aging. J Gerontol A Biol Sci Med Sci. 2017:72:1218-25.

19. Prattichizzo F, Micolucci L, Cricca M, De Carolis S, Mensà E, Ceriello A, et al. Exosome-based immunomodulation during aging: a nano-perspective on inflamm-aging. Mech Ageing Dev. 2017;168:44-53.

20. Xu D, Tahara $H$. The role of exosomes and microRNAs in senescence and aging. Adv Drug Deliv Rev. 2013;65:368-75.

21. Nanayakkara S, Marwick TH, Kaye DM. The ageing heart: the systemic and coronary circulation. Heart. 2018;104:370-6.

22. Nagata K, Yamazaki T, Takano D, Maeda T, Fujimaki Y, Nakase T, et al. Cerebral circulation in aging. Ageing Res Rev. 2016;30:49.

23. Epstein SE, Lassance-Soares RM, Faber JE, Burnett MS. Effects of aging on the collateral circulation, and therapeutic implications. Circulation. 2012;125:3211-9.

24. Fabbri E, An Y, Zoli M, Simonsick EM, Guralnik JM, Bandinelli S, et al. Aging and the burden of multimorbidity: associations with inflammatory and anabolic hormonal biomarkers. J Gerontol. 2015;70:63-70.

25. Fujisawa K. Some observations on the skeletal musculature of aged rats. I. Histological aspects. J Neurol Sci. 1974;22:353-66.

26. Fujisawa K. Some observations on the skeletal musculature of aged rats. Part 2. Fine morphology of diseased muscle fibres. J Neurol Sci. 1975;24:447-69.

27. Tomonaga M. Histochemical and ultrastructural changes in senile human skeletal muscle. J Am Geriatr Soc. 1977;25:125-31.

28. Marzetti E, Leeuwenburgh C. Skeletal muscle apoptosis, sarcopenia and frailty at old age. Exp Gerontol. 2006;41:1234-8.

29. Aiken J, Bua E, Cao Z, Lopez M, Wanagat J, McKenzie D, et al. Mitochondrial DNA deletion mutations and sarcopenia. Ann N Y Acad Sci. 2002;959:412-23.

30. Szczesny B, Tann AW, Mitra S. Age- and tissue-specific changes in mitochondrial and nuclear DNA base excision repair activity in mice: susceptibility of skeletal muscles to oxidative injury. Mech Ageing Dev. 2010;131:330-7.

31. Kreiling JA, Tamamori-Adachi M, Sexton AN, Jeyapalan JC, Munoz-Najar U, Peterson AL, et al. Age-associated increase in heterochromatic marks in murine and primate tissues. Aging Cell. 2011;10:292-304.

32. Yarasheski KE, Pak-Loduca J, Hasten DL, Obert KA, Brown MB, Sinacore DR. Resistance exercise training increases mixed muscle protein synthesis rate in frail women and men >/=76 yr old. Am J Phys. 1999;277:E118-25.

33. Hasten DL, Pak-Loduca J, Obert KA, Yarasheski KE. Resistance exercise acutely increases MHC and mixed muscle protein synthesis rates in 78-84 and 23-32 yr olds. Am J Physiol Endocrinol Metab. 2000;278:E620-6.

34. Wohlgemuth SE, Seo AY, Marzetti E, Lees HA, Leeuwenburgh C. Skeletal muscle autophagy and apoptosis during aging: effects of calorie restriction and life-long exercise. Exp Gerontol. 2010;45:138-48.

35. Beregi E, Regius O, Hüttl T, Göbl Z. Age-related changes in the skeletal muscle cells. Z Gerontol. 1988;21:83-6.

36. Hütter E, Skovbro M, Lener B, Prats C, Rabøl R, Dela F, et al. Oxidative stress and mitochondrial impairment can be separated from lipofuscin accumulation in aged human skeletal muscle. Aging Cell. 2007;6:245-56.

37. Snow LM, Fugere NA, Thompson LV. Advanced glycation end-product accumulation and associated protein modification in type II skeletal muscle with aging. J Gerontol A Biol Sci Med Sci. 2007;62:1204-10.

38. Yamaguchi T, Arai H, Katayama N, Ishikawa T, Kikumoto K, Atomi Y. Age-related increase of insoluble, phosphorylated small heat shock proteins in human skeletal muscle. J Gerontol A Biol Sci Med Sci. 2007; 62:481-9.

39. Drummond MJ, McCarthy JJ, Sinha M, Spratt HM, Volpi E, Esser KA, et al. Aging and microRNA expression in human skeletal muscle: a microarray and bioinformatics analysis. Physiol Genomics. 2011;43:595-603. 
40. Cristea A, Qaisar R, Edlund PK, Lindblad J, Bengtsson E, Larsson L. Effects of aging and gender on the spatial organization of nuclei in single human skeletal muscle cells. Aging Cell. 2010;9:685-97.

41. Oh J, Lee YD, Wagers AJ. Stem cell aging: mechanisms, regulators and therapeutic opportunities. Nat Med. 2014;20:870-80.

42. Neves J, Sousa-Victor P, Jasper H. Rejuvenating strategies for stem cellbased therapies in aging. Cell Stem Cell. 2017;20:161-75.

43. Feige P, Brun CE, Ritso M, Rudnicki MA. Orienting muscle stem cells for regeneration in homeostasis, aging, and disease. Cell Stem Cell. 2018;23: 653-64.

44. Waltz TB, Fivenson EM, Morevati M, Li C, Becker KG, Bohr VA, et al. Sarcopenia, aging and prospective interventional strategies. Curr Med Chem. 2018;25:5588-96.

45. Larsson L, Degens H, Li M, Salviati L, Lee YI, Thompson W, et al. Sarcopenia: aging-related loss of muscle mass and function. Physiol Rev. 2019;99:427-511.

46. Dalle S, Rossmeislova L, Koppo K. The role of inflammation in age-related sarcopenia. Front Physiol. 2017:8:1045.

47. Snijders T, Parise G. Role of muscle stem cells in sarcopenia. Curr Opin Clin Nutr Metab Care. 2017;20:186

48. Laurent MR, Dedeyne L, Dupont J, Mellaerts B, Dejaeger M, Gielen E. Agerelated bone loss and sarcopenia in men. Maturitas. 2019;122:51-6.

49. Conboy IM, Rando TA. The regulation of Notch signaling controls satellite cell activation and cell fate determination in postnatal myogenesis. Dev Cell. 2002;3:397-409

50. Brack AS, Conboy IM, Conboy MJ, Shen J, Rando TA. A temporal switch from notch to Wnt signaling in muscle stem cells is necessary for normal adult myogenesis. Cell Stem Cell. 2008;2:50-9.

51. Conboy IM, Conboy MJ, Smythe GM, Rando TA. Notch-mediated restoration of regenerative potential to aged muscle. Science. 2003:302:1575-7.

52. Chakkalakal JV, Jones KM, Basson MA, Brack AS. The aged niche disrupts muscle stem cell quiescence. Nature. 2012;490:355-60.

53. Price FD, von Maltzahn J, Bentzinger CF, Dumont NA, Yin $\mathrm{H}$, Chang NC, et al. Inhibition of JAK-STAT signaling stimulates adult satellite cell function. Nat Med. 2014:20:1174-81.

54. Mauro A. Satellite cell of skeletal muscle fibers. J Biophys Biochem Cytol. 1961;9:493-5.

55. Montarras D. Direct isolation of satellite cells for skeletal muscle regeneration. Science. 2005:309:2064-7.

56. Mesires NT, Doumit ME. Satellite cell proliferation and differentiation during postnatal growth of porcine skeletal muscle. Am J Phys-Cell Phys. 2002;282: C899-906.

57. Mau M, Oksbjerg N, Rehfeldt C. Establishment and conditions for growth and differentiation of a myoblast cell line derived from the semimembranosus muscle of newborn piglets. In Vitro Cell Dev Biol Anim 2008:44:1-5.

58. Meech R, Gonzalez KN, Barro M, Gromova A, Zhuang L, Hulin J-A, et al. Barx2 is expressed in satellite cells and is required for normal muscle growth and regeneration. Stem Cells. 2012;30:253-65.

59. Allen RE, Sheehan SM, Taylor RG, Kendall TL, Rice GM. Hepatocyte growth factor activates quiescent skeletal muscle satellite cells in vitro. J Cell Physiol. 1995;165:307-12.

60. Fukada S, Uezumi A, Ikemoto M, Masuda S, Segawa M, Tanimura N, et al. Molecular signature of quiescent satellite cells in adult skeletal muscle. Stem Cells. 2007;25:2448-59.

61. Gnocchi VF, White RB, Ono Y, Ellis JA, Zammit PS. Further characterisation of the molecular signature of quiescent and activated mouse muscle satellite cells. PLoS One. 2009;4:e5205.

62. Beauchamp JR, Heslop L, Yu DS, Tajbakhsh S, Kelly RG, Wernig A, et al. Expression of CD34 and Myf5 defines the majority of quiescent adult skeletal muscle satellite cells. J Cell Biol. 2000;151:1221-34.

63. Boldrin L, Muntoni F, Morgan JE. Are human and mouse satellite cells really the same? J Histochem Cytochem. 2010;58:941-55.

64. Castiglioni A, Hettmer S, Lynes MD, Rao TN, Tchessalova D, Sinha I, et al. Isolation of progenitors that exhibit myogenic/osteogenic bipotency in vitro by fluorescence-activated cell sorting from human fetal muscle. Stem Cell Reports. 2014:2:92-106

65. Ratajczak MZ, Majka M, Kucia M, Drukala J, Pietrzkowski Z, Peiper S, et al. Expression of functional CXCR4 by muscle satellite cells and secretion of SDF-1 by muscle-derived fibroblasts is associated with the presence of both muscle progenitors in bone marrow and hematopoietic stem/progenitor cells in muscles. Stem Cells. 2003;21:363-71.
66. Sherwood Rl, Christensen JL, Conboy IM, Conboy MJ, Rando TA, Weissman IL, et al. Isolation of adult mouse myogenic progenitors: functional heterogeneity of cells within and engrafting skeletal muscle. Cell. 2004;119: $543-54$.

67. Chapman MR, Balakrishnan K, Li J, Conboy MJ, Huang H, Mohanty SK, et al. Sorting single satellite cells from individual myofibers reveals heterogeneity in cell-surface markers and myogenic capacity. Integr Biol (Camb). 2013;5: 692-702.

68. Maesner CC, Almada AE, Wagers AJ. Established cell surface markers efficiently isolate highly overlapping populations of skeletal muscle satellite cells by fluorescence-activated cell sorting. Skelet Muscle. 2016;6:35 [Cited 2019 May 31] Available from: https://www.ncbi.nlm.nih.gov/pmc/articles/ PMC5100091/.

69. Buckingham M, Bajard L, Chang T, Daubas P, Hadchouel J, Meilhac S, et al. The formation of skeletal muscle: from somite to limb. J Anat. 2003;202:59-68.

70. Cornelison DDW, Filla MS, Stanley HM, Rapraeger AC, Olwin BB. Syndecan-3 and syndecan-4 specifically mark skeletal muscle satellite cells and are implicated in satellite cell maintenance and muscle regeneration. Dev Biol. 2001:239:79-94

71. Seale P, Sabourin LA, Girgis-Gabardo A, Mansouri A, Gruss P, Rudnicki MA. Pax7 is required for the specification of myogenic satellite cells. Cell. 2000; 102:777-86.

72. Yin H, Price F, Rudnicki MA. Satellite cells and the muscle stem cell niche. Physiol Rev. 2013;93:23-67.

73. Sacco A, Doyonnas R, Kraft P, Vitorovic S, Blau HM. Self-renewal and expansion of single transplanted muscle stem cells. Nature. 2008;456:502-6.

74. Sahu A, Mamiya H, Shinde SN, Cheikhi A, Winter LL, Vo NV, et al. Agerelated declines in a-Klotho drive progenitor cell mitochondrial dysfunction and impaired muscle regeneration. Nat Commun. 2018;9:4859.

75. Jones NC, Tyner KJ, Nibarger L, Stanley HM, Cornelison DDW, Fedorov YV, et al. The p38a/ $\beta$ MAPK functions as a molecular switch to activate the quiescent satellite cell. J Cell Biol. 2005;169:105-16.

76. Matsuyoshi Y, Akahoshi M, Nakamura M, Tatsumi R, Mizunoya W. Isolation and purification of satellite cells from young rats by percoll density gradient centrifugation. Methods Mol Biol. 2019;1889:81-93.

77. Rando TA, Pavlath GK, Blau HM. The fate of myoblasts following transplantation into mature muscle. Exp Cell Res. 1995;220:383-9.

78. Conboy MJ, Conboy IM. Preparation of adult muscle fiber-associated stem/ precursor cells. Methods Mol Biol. 2010;621:149-63.

79. Mehdipour M, Liu Y, Liu C, Kumar B, Kim D, Gathwala R, et al. Key ageimposed signaling changes that are responsible for the decline of stem cell function. Subcell Biochem. 2018;90:119-43.

80. Doumit ME, Merkel RA. Conditions for isolation and culture of porcine myogenic satellite cells. Tissue Cell. 1992;24:253-62.

81. Zammit PS, Partridge TA, Yablonka-Reuveni Z. The skeletal muscle satellite cell: the stem cell that came in from the cold. J Histochem Cytochem. 2006;54:1177-91.

82. Wei Y, Li Y, Chen C, Stoelzel K, Kaufmann AM, Albers AE. Human skeletal muscle-derived stem cells retain stem cell properties after expansion in myosphere culture. Exp Cell Res. 2011:317:1016-27.

83. Chirieleison SM, Feduska JM, Schugar RC, Askew Y, Deasy BM. Human muscle-derived cell populations isolated by differential adhesion rates: phenotype and contribution to skeletal muscle regeneration in Mdx/SCID mice. Tissue Eng Part A. 2012;18:232-41.

84. Li J, Han S, Cousin W, Conboy IM. Age-specific functional epigenetic changes in p21 and p16 in injury-activated satellite cells. Stem Cells. 2015; 33:951-61.

85. Cousin W, Ho ML, Desai R, Tham A, Chen RY, Kung S, et al. Regenerative capacity of old muscle stem cells declines without significant accumulation of DNA damage. PLoS One. 2013;8:e63528.

86. Elabd C, Cousin W, Upadhyayula P, Chen RY, Chooljian MS, Li J, et al. Oxytocin is an age-specific circulating hormone that is necessary for muscle maintenance and regeneration. Nat Commun. 2014;5:4082.

87. Paliwal P, Pishesha N, Wijaya D, Conboy IM. Age dependent increase in the levels of osteopontin inhibits skeletal muscle regeneration. Aging (Albany NY). 2012;4:553-66.

88. Christov C, Chrétien F, Abou-Khalil R, Bassez G, Vallet G, Authier F-J, et al. Muscle satellite cells and endothelial cells: close neighbors and privileged partners. Mol Biol Cell. 2007:18:1397-409.

89. Rocheteau P, Gayraud-Morel B, Siegl-Cachedenier I, Blasco MA, Tajbakhsh S. A subpopulation of adult skeletal muscle stem cells retains all template DNA strands after cell division. Cell. 2012;148:112-25. 
90. Verdijk LB, Snijders T, Drost M, Delhaas T, Kadi F, van Loon LC. Satellite cells in human skeletal muscle; from birth to old age. Age (Dordr). 2014;36:545-57.

91. Almada AE, Wagers AJ. Molecular circuitry of stem cell fate in skeletal muscle regeneration, ageing, and disease. Nat Rev Mol Cell Biol. 2016;17:267-79.

92. Shefer G, Rauner G, Yablonka-Reuveni Z, Benayahu D. Reduced satellite cell numbers and myogenic capacity in aging can be alleviated by endurance exercise. PLoS One. 2010;5:e13307.

93. Day K, Shefer G, Shearer A, Yablonka-Reuveni Z. The depletion of skeletal muscle satellite cells with age is concomitant with reduced capacity of single progenitors to produce reserve progeny. Dev Biol. 2010;340:330-43.

94. Shefer G, Van de Mark DP, Richardson JB, Yablonka-Reuveni Z. Satellite-cell pool size does matter: defining the myogenic potency of aging skeletal muscle. Dev Biol. 2006;294:50-66.

95. Bosnakovski D, Xu Z, Li W, Thet S, Cleaver O, RCR P, et al. Prospective isolation of skeletal muscle stem cells with a Pax7 reporter. Stem Cells. 2008; 26:3194-204.

96. Sousa-Victor P, Gutarra S, García-Prat L, Rodriguez-Ubreva J, Ortet L, RuizBonilla V, et al. Geriatric muscle stem cells switch reversible quiescence into senescence. Nature. 2014;506:316-21.

97. Brack AS, Muñoz-Cánoves P. The ins and outs of muscle stem cell aging. Skelet Muscle. 2016;6:1 [Cited 2019 Oct 31] Available from: https://www. ncbi.nlm.nih.gov/pmc/articles/PMC4716636/.

98. Brack AS, Rando TA. Intrinsic changes and extrinsic influences of myogenic stem cell function during aging. Stem Cell Rev. 2007;3:226-37.

99. Rando TA, Blau HM. Primary mouse myoblast purification, characterization, and transplantation for cell-mediated gene therapy. J Cell Biol. 1994;125: 1275-87.

100. Pietrosemoli N, Mella S, Yennek S, Baghdadi MB, Sakai H, Sambasivan R, et al. Comparison of multiple transcriptomes exposes unified and divergent features of quiescent and activated skeletal muscle stem cells. Skelet Muscle. 2017;7:28.

101. Bachman JF, Klose A, Liu W, Paris ND, Blanc RS, Schmalz M, et al. Prepubertal skeletal muscle growth requires Pax7-expressing satellite cellderived myonuclear contribution. Development. 2018;145:dev167197.

102. Bischoff R. The satellite cell and muscle regeneration. Myology. 1994; [Cited 2019 Jun 4]; Available from: https://ci.nii.ac.jp/naid/10018625843/.

103. Snow MH. The effects of aging on satellite cells in skeletal muscles of mice and rats. Cell Tissue Res. 1977;185:399-408.

104. Gibson MC, Schultz E. The distribution of satellite cells and their relationship to specific fiber types in soleus and extensor digitorum longus muscles. Anat Rec. 1982;202:329-37.

105. Egner IM, Bruusgaard JC, Gundersen K. Satellite cell depletion prevents fiber hypertrophy in skeletal muscle. Development. 2016;143:2898-906.

106. Rodriguez J, Vernus B, Chelh I, Cassar-Malek I, Gabillard JC, Hadj Sassi A, et al. Myostatin and the skeletal muscle atrophy and hypertrophy signaling pathways. Cell Mol Life Sci. 2014;71:4361-71.

107. Murach KA, Fry CS, Kirby TJ, Jackson JR, Lee JD, White SH, et al. Starring or supporting role? Satellite cells and skeletal muscle fiber size regulation. Physiology (Bethesda). 2018;33:26-38.

108. McCarthy JJ, Mula J, Miyazaki M, Erfani R, Garrison K, Farooqui AB, et al. Effective fiber hypertrophy in satellite cell-depleted skeletal muscle. Development. 2011;138:3657-66.

109. Murach KA, Confides AL, Ho A, Jackson JR, Ghazala LS, Peterson CA, et al. Depletion of Pax7+ satellite cells does not affect diaphragm adaptations to running in young or aged mice. J Physiol. 2017;595:6299-311.

110. Fry CS, Lee JD, Jackson JR, Kirby TJ, Stasko SA, Liu H, et al. Regulation of the muscle fiber microenvironment by activated satellite cells during hypertrophy. FASEB J. 2014;28:1654-65.

111. Liu W, Klose A, Forman S, Paris ND, Wei-LaPierre L, Cortés-Lopéz M, et al. Loss of adult skeletal muscle stem cells drives age-related neuromuscular junction degeneration. eLife. 2017;6:e26464.

112. Collins CA, Olsen I, Zammit PS, Heslop L, Petrie A, Partridge TA, et al. Stem cell function, self-renewal, and behavioral heterogeneity of cells from the adult muscle satellite cell niche. Cell. 2005;122:289-301.

113. Hardy D, Besnard A, Latil M, Jouvion G, Briand D, Thépenier C, et al. Comparative study of injury models for studying muscle regeneration in mice. PLoS One. 2016;11 [Cited 2019 Nov 2] Available from: https://www. ncbi.nlm.nih.gov/pmc/articles/PMC4726569/.

114. Bockhold KJ, Rosenblatt JD, Partridge TA. Aging normal and dystrophic mouse muscle: analysis of myogenicity in cultures of living single fibers. Muscle Nerve. 1998;21:173-83.
115. Collins CA, Zammit PS, Ruiz AP, Morgan JE, Partridge TA. A population of myogenic stem cells that survives skeletal muscle aging. Stem Cells. 2007: 25:885-94.

116. Bernet JD, Doles JD, Hall JK, Kelly Tanaka K, Carter TA, Olwin BB. p38 MAPK signaling underlies a cell-autonomous loss of stem cell self-renewal in skeletal muscle of aged mice. Nat Med. 2014;20:265-71.

117. Cosgrove BD, Gilbert PM, Porpiglia E, Mourkioti F, Lee SP, Corbel SY, et al. Rejuvenation of the muscle stem cell population restores strength to injured aged muscles. Nat Med. 2014;20:255-64.

118. Tierney MT, Aydogdu T, Sala D, Malecova B, Gatto S, Puri PL, et al. STAT3 signaling controls satellite cell expansion and skeletal muscle repair. Nat Med. 2014;20:1182-6.

119. Doles J, Storer M, Cozzuto L, Roma G, Keyes WM. Age-associated inflammation inhibits epidermal stem cell function. Genes Dev. 2012;26: 2144-53.

120. Jiang $H$, Tian A, Jiang J. Intestinal stem cell response to injury: lessons from Drosophila. Cell Mol Life Sci. 2016;73:3337-49.

121. Zhang R, Engler A, Taylor V. Notch: an interactive player in neurogenesis and disease. Cell Tissue Res. 2018;371:73-89.

122. Moparthi L, Koch S. Wnt signaling in intestinal inflammation. Differentiation. 2019;108:24-32.

123. Kopan R, Nye JS, Weintraub H. The intracellular domain of mouse Notch: a constitutively activated repressor of myogenesis directed at the basic helixloop-helix region of MyoD. Development. 1994;120:2385-96.

124. Shawber C, Nofziger D, Hsieh JJD, Lindsell C, Bögler O, Hayward D, et al. Notch signaling inhibits muscle cell differentiation through a CBF1independent pathway. Development. 1996;122:3765-73.

125. Lindsell CE, Shawber CJ, Boulter J, Weinmaster G. Jagged: a mammalian ligand that activates Notch1. Cell. 1995;80:909-17.

126. Nofziger D, Miyamoto A, Lyons KM, Weinmaster G. Notch signaling imposes two distinct blocks in the differentiation of $\mathrm{C} 2 \mathrm{C} 12$ myoblasts. Development. 1999:126:1689-702.

127. Kuang S, Kuroda K, Le Grand F, Rudnicki MA. Asymmetric self-renewal and commitment of satellite stem cells in muscle. Cell. 2007:129:999-1010.

128. Foster RF, Thompson JM, Kaufman SJ. A laminin substrate promotes myogenesis in rat skeletal muscle cultures: analysis of replication and development using antidesmin and anti-BrdUrd monoclonal antibodies. Dev Biol. 1987:122:11-20.

129. Ocalan M, Goodman SL, Kühl U, Hauschka SD, von der Mark K. Laminin alters cell shape and stimulates motility and proliferation of murine skeletal myoblasts. Dev Biol. 1988;125:158-67.

130. Lukjanenko L, Jung MJ, Hegde N, Perruisseau-Carrier C, Migliavacca E, Rozo $\mathrm{M}$, et al. Loss of fibronectin from the aged stem cell niche affects the regenerative capacity of skeletal muscle in mice. Nat Med. 2016;22:897-905.

131. Troy A, Cadwallader AB, Fedorov Y, Tyner K, Tanaka KK, Olwin BB. Coordination of satellite cell activation and self-renewal by Par-complex-dependent asymmetric activation of p38a/B MAPK. Cell Stem Cell. 2012;11:541-53.

132. Paris ND, Soroka A, Klose A, Liu W, Chakkalakal JV. Smad4 restricts differentiation to promote expansion of satellite cell derived progenitors during skeletal muscle regeneration. Wagers AJ, editor. eLife. 2016;5:e19484.

133. Sadeh M. Effects of aging on skeletal muscle regeneration. J Neurol Sci. 1988;87:67-74.

134. Han WM, Anderson SE, Mohiuddin M, Barros D, Nakhai SA, Shin E, et al. Synthetic matrix enhances transplanted satellite cell engraftment in dystrophic and aged skeletal muscle with comorbid trauma. Sci Adv. 2018;4: eaar4008.

135. Tichy ED, Sidibe DK, Greer CD, Oyster NM, Rompolas P, Rosenthal NA, et al. A robust Pax7EGFP mouse that enables the visualization of dynamic behaviors of muscle stem cells. Skelet Muscle. 2018;8:27.

136. Cerletti M, Jang YC, Finley LWS, Haigis MC, Wagers AJ. Short-term calorie restriction enhances skeletal muscle stem cell function. Cell Stem Cell. 2012; 10:515-9.

137. Day K, Shefer G, Richardson JB, Enikolopov G, Yablonka-Reuveni Z. NestinGFP reporter expression defines the quiescent state of skeletal muscle satellite cells. Dev Biol. 2007;304:246-59.

138. Montarras D, Morgan J, Collins C, Relaix F, Zaffran S, Cumano A, et al. Direct isolation of satellite cells for skeletal muscle regeneration. Science. 2005;309: 2064-7.

139. Mourikis P, Sambasivan R, Castel D, Rocheteau P, Bizzarro V, Tajbakhsh S. A critical requirement for notch signaling in maintenance of the quiescent skeletal muscle stem cell state. Stem Cells. 2012;30:243-52. 
140. Boppart MD, Burkin DJ, Kaufman SJ. a7ß1-Integrin regulates mechanotransduction and prevents skeletal muscle injury. Am J Physiol-Cell Physiol. 2006;290:C1660-5.

141. Carlson BM, Faulkner JA. Muscle transplantation between young and old rats: age of host determines recovery. Am J Physiol-Cell Physiol. 1989;256:C1262-6.

142. Sinha M, Jang YC, Oh J, Khong D, Wu EY, Manohar R, et al. Restoring systemic GDF11 levels reverses age-related dysfunction in mouse skeletal muscle. Science. 2014;344:649-52.

143. Rebo J, Mehdipour M, Gathwala R, Causey K, Liu Y, Conboy MJ, et al. A single heterochronic blood exchange reveals rapid inhibition of multiple tissues by old blood. Nat Commun. 2016;7:13363.

144. Pratiwi YS, Lesmana R, Goenawan H, Sylviana N, Setiawan I, Tarawan VM, et al. Nutmeg extract increases skeletal muscle mass in aging rats partly via IGF1-AKT-mTOR pathway and inhibition of autophagy. Evid Based Complement Alternat Med. 2018:2018:2810840.

145. Hinken AC, Powers JM, Luo G, Holt JA, Billin AN, Russell AJ. Lack of evidence for GDF11 as a rejuvenator of aged skeletal muscle satellite cells. Aging Cell. 2016;15:582-4

146. McPherron AC, Huynh TV, Lee S-J. Redundancy of myostatin and growth/ differentiation factor 11 function. BMC Dev Biol. 2009;9:24.

147. Jeanplong F, Falconer SJ, Thomas M, Matthews KG, Oldham JM, Watson T, et al. Growth and differentiation factor-11 is developmentally regulated in skeletal muscle and inhibits myoblast differentiation. OJMIP. 2012;02:127-38.

148. Mehdipour M, Etienne J, Chen C-C, Gathwala R, Rehman M, Kato C, et al. Rejuvenation of brain, liver and muscle by simultaneous pharmacological modulation of two signaling determinants, that change in opposite directions with age. Aging (Albany NY). 2019;11:5628-45.

149. Egerman MA, Cadena SM, Gilbert JA, Meyer A, Nelson HN, Swalley SE, et al. GDF11 increases with age and inhibits skeletal muscle regeneration. Cell Metab. 2015:22:164-74

150. McPherron AC, Lawler AM, Lee S-J. Regulation of anterior/posterior patterning of the axial skeleton by growth/differentiation factor 11. Nat Genet. 1999;22:260.

151. Hammers DW, Merscham-Banda M, Hsiao JY, Engst S, Hartman JJ, Sweeney $\mathrm{HL}$. Supraphysiological levels of GDF11 induce striated muscle atrophy. EMBO Mol Med. 2017:9:531-44.

152. McPherron AC, Lawler AM, Lee SJ. Regulation of skeletal muscle mass in mice by a new TGF-beta superfamily member. Nature. 1997:387:83-90.

153. Lee S-J, Lee Y-S, Zimmers TA, Soleimani A, Matzuk MM, Tsuchida K, et al. Regulation of muscle mass by follistatin and activins. Mol Endocrinol. 2010; 24:1998-2008

154. Lee Y-S, Lee S-J. Regulation of GDF-11 and myostatin activity by GASP-1 and GASP-2. Proc Natl Acad Sci U S A. 2013;110:E3713-22.

155. Yokoe T, Ohmachi T, Inoue H, Mimori K, Tanaka F, Kusunoki M, et al. Clinical significance of growth differentiation factor 11 in colorectal cancer. Int J Oncol. 2007;31:1097-101

156. Zhang Y, Pan L, Pang Y, Yang J, Lv M, Liu F, et al. GDF11/BMP11 as a novel tumor marker for liver cancer. Exp Ther Med. 2018;15:3495.

157. Zhang J, Li Y, Li H, Zhu B, Wang L, Guo B, et al. GDF11 improves angiogenic function of EPCs in diabetic limb ischemia. Diabetes. 2018;67:2084-95.

158. Yu X, Chen X, Dong Zheng X, Zhang J, Zhao X, Liu Y, et al. Growth differentiation factor 11 promotes abnormal proliferation and angiogenesis of pulmonary artery endothelial cells. Hypertension. 2018;71:729 HYPERTENSIONAHA.117.10350.

159. Goulas S, Conder R, Knoblich JA. The Par complex and integrins direct asymmetric cell division in adult intestinal stem cells. Cell Stem Cell. 2012; 11:529-40.

160. Urciuolo A, Quarta M, Morbidoni V, Gattazzo F, Molon S, Grumati P, et al. Collagen VI regulates satellite cell self-renewal and muscle regeneration. Nat Commun. 2013:4:1964.

161. Gilbert PM, Havenstrite KL, Magnusson KEG, Sacco A, Leonardi NA, Kraft P, et al. Substrate elasticity regulates skeletal muscle stem cell self-renewal in culture. Science. 2010;329:1078-81.

162. Podleski TR, Greenberg I, Schlessinger J, Yamada KM. Fibronectin delays the fusion of L6 myoblasts. Exp Cell Res. 1979;122:317-26.

163. Yamada M, Tatsumi R, Kikuiri T, Okamoto S, Nonoshita S, Mizunoya W, et al. Matrix metalloproteinases are involved in mechanical stretch-induced activation of skeletal muscle satellite cells. Muscle Nerve. 2006:34:313-9.

164. Shimomura T, Kondo J, Ochiai M, Naka D, Miyazawa K, Morimoto Y, et al. Activation of the zymogen of hepatocyte growth factor activator by thrombin. J Biol Chem. 1993;268:22927-32.
165. Fry CS, Lee JD, Mula J, Kirby TJ, Jackson JR, Liu F, et al. Inducible depletion of satellite cells in adult, sedentary mice impairs muscle regenerative capacity without affecting sarcopenia. Nat Med. 2015;21:76-80.

166. Labat-Robert J, Robert L. Interaction between cells and extracellular matrix signaling by integrins and the elastin-laminin receptor. In: Macieira-Coelho A, editor. Signaling Through the Cell Matrix. Berlin, Heidelberg: Springer; 2000. p. 57-70. [Cited 2019 Oct 29]. https://doi.org/10.1007/978-3-64259766-4_4.

167. Matrbian LM. Metalloproteinases and their inhibitors in matrix remodeling. :5.

168. Thorsteinsdóttir S, Deries M, Cachaço AS, Bajanca F. The extracellular matrix dimension of skeletal muscle development. Dev Biol. 2011;354:191-207.

169. Kothari P, Pestana R, Mesraoua R, Elchaki R, Khan KMF, Dannenberg AJ, et al. IL-6-mediated induction of MMP-9 is modulated by JAK-dependent IL-10 expression in macrophages. J Immunol. 2014;192:349 [Cited 2019 Jul 6] Available from: https://www.ncbi.nlm.nih.gov/pmc/articles/PMC3872272/.

170. Kherif S, Lafuma C, Dehaupas M, Lachkar S, Fournier J-G, Verdière-Sahuqué $M$, et al. Expression of matrix metalloproteinases 2 and 9 in regenerating skeletal muscle: a study in experimentally injured andmdxmuscles. Dev Biol. 1999:205:158-70.

171. Yu J, Deuel TF, Kim HR. Platelet-derived growth factor (PDGF) receptor-alpha activates C-Jun NH2-terminal kinase-1 and antagonizes PDGF receptor-beta -induced phenotypic transformation. J Biol Chem. 2000;275:19076-82.

172. Philippou A, Maridaki M, Koutsilieris M. The role of urokinase-type plasminogen activator (UPA) and transforming growth factor beta 1 (TGFbeta1) in muscle regeneration. In Vivo. 2008;22:735-50.

173. Marshall PA, Williams PE, Goldspink G. Accumulation of collagen and altered fiber-type ratios as indicators of abnormal muscle gene expression in the mdx dystrophic mouse. Muscle Nerve. 1989;12:528-37.

174. Alexakis C, Partridge T, Bou-Gharios G. Implication of the satellite cell in dystrophic muscle fibrosis: a self-perpetuating mechanism of collagen overproduction. Am J Phys Cell Phys. 2007;293:C661-9.

175. Lacraz G, Rouleau A-J, Couture V, Söllrald T, Drouin G, Veillette N, et al. Increased stiffness in aged skeletal muscle impairs muscle progenitor cell proliferative activity. PLoS One. 2015;10:e0136217.

176. Wood LK, Kayupov E, Gumucio JP, Mendias CL, Claflin DR, Brooks SV. Intrinsic stiffness of extracellular matrix increases with age in skeletal muscles of mice. J Appl Physiol. 2014;117:363-9.

177. Vracko R, Benditt EP. Basal lamina: the scaffold for orderly cell replacement. Observations on regeneration of injured skeletal muscle fibers and capillaries. J Cell Biol. 1972;55:406-19.

178. Sanes JR. Reinnervation of muscle fiber basal lamina after removal of myofibers. Differentiation of regenerating axons at original synaptic sites. J Cell Biol. 1978;78:176-98.

179. Sanes JR. The basement membrane/basal lamina of skeletal muscle. J Biol Chem. 2003;278:12601-4

180. Lv H, Li L, Sun M, Zhang Y, Chen L, Rong Y, et al. Mechanism of regulation of stem cell differentiation by matrix stiffness. Stem Cell Res Ther. 2015;6:103.

181. Dupont S, Morsut L, Aragona M, Enzo E, Giulitti S, Cordenonsi M, et al. Role of YAP/TAZ in mechanotransduction. Nature. 2011:474:179-83.

182. Pelissier FA, Garbe JC, Ananthanarayanan B, Miyano M, Lin C, Jokela T, et al. Age-related dysfunction in mechanotransduction impairs differentiation of human mammary epithelial progenitors. Cell Rep. 2014;7:1926-39.

183. Stearns-Reider KM, D'Amore A, Beezhold K, Rothrauff B, Cavalli L, Wagner WR, et al. Aging of the skeletal muscle extracellular matrix drives a stem cell fibrogenic conversion. Aging Cell. 2017;16:518-28.

184. Halder G, Dupont S, Piccolo S. Transduction of mechanical and cytoskeletal cues by YAP and TAZ. Nat Rev Mol Cell Biol. 2012;13:591-600.

185. Graham DM, Burridge K. Mechanotransduction and nuclear function. Curr Opin Cell Biol. 2016;40:98-105.

186. Smith L, Cho S, Discher DE. Mechanosensing of matrix by stem cells: from matrix heterogeneity, contractility, and the nucleus in pore-migration to cardiogenesis and muscle stem cells in vivo. Semin Cell Dev Biol. 2017:71:84-98.

187. Liu L, Cheung TH, Charville GW, Hurgo BMC, Leavitt T, Shih J, et al. Chromatin modifications as determinants of muscle stem cell quiescence and chronological aging. Cell Rep. 2013;4:189-204.

188. Benayoun BA, Pollina EA, Singh PP, Mahmoudi S, Harel I, Casey KM, et al. Remodeling of epigenome and transcriptome landscapes with aging in mice reveals widespread induction of inflammatory responses. Genome Res. 2019;29:697-709.

189. Mertens J, Paquola ACM, Ku M, Hatch E, Böhnke L, Ladjevardi S, et al. Directly reprogrammed human neurons retain aging-associated 
transcriptomic signatures and reveal age-related nucleocytoplasmic defects. Cell Stem Cell. 2015;17:705-18.

190. Fan X, Khaki L, Zhu TS, Soules ME, Talsma CE, Gul N, et al. NOTCH pathway blockade depletes CD133-positive glioblastoma cells and inhibits growth of tumor neurospheres and xenografts. Stem Cells. 2010;28:5-16.

191. Schaller MA, Logue H, Mukherjee S, Lindell DM, Coelho AL, Lincoln P, et al. Delta-like 4 differentially regulates murine CD4 T cell expansion via BMI1. PLoS One. 2010;5:e12172.

192. Jacobs JJ, Kieboom K, Marino S, DePinho RA, van Lohuizen M. The oncogene and Polycomb-group gene bmi-1 regulates cell proliferation and senescence through the ink4a locus. Nature. 1999;397:164-8.

193. Bracken AP, Kleine-Kohlbrecher D, Dietrich N, Pasini D, Gargiulo G, Beekman $C$, et al. The Polycomb group proteins bind throughout the INK4A-ARF locus and are disassociated in senescent cells. Genes Dev. 2007;21:525-30.

194. Barski A, Cuddapah S, Cui K, Roh T-Y, Schones DE, Wang Z, et al. Highresolution profiling of histone methylations in the human genome. Cell. 2007;129:823-37.

195. Ku M, Koche RP, Rheinbay E, Mendenhall EM, Endoh M, Mikkelsen TS, et al. Genomewide analysis of PRC1 and PRC2 occupancy identifies two classes of bivalent domains. PLoS Genet. 2008;4:e1000242.

196. Oguro H, Yuan J, Ichikawa H, Ikawa T, Yamazaki S, Kawamoto H, et al. Poised lineage specification in multipotential hematopoietic stem and progenitor cells by the polycomb protein Bmi1. Cell Stem Cell. 2010;6:279-86.

197. Robson LG, Di Foggia V, Radunovic A, Bird K, Zhang X, Marino S. Bmi1 is expressed in postnatal myogenic satellite cells, controls their maintenance and plays an essential role in repeated muscle regeneration. PLoS One. 2011;6:e27116.

198. Yousef H, Conboy MJ, Morgenthaler A, Schlesinger C, Bugaj L, Paliwal P, et al. Systemic attenuation of the TGF- $\beta$ pathway by a single drug simultaneously rejuvenates hippocampal neurogenesis and myogenesis in the same old mammal. Oncotarget. 2015;6:11959-78.

199. Schwörer S, Becker F, Feller C, Baig AH, Köber U, Henze H, et al. Epigenetic stress responses induce muscle stem-cell ageing by Hoxa9 developmental signals. Nature. 2016;540:428-32.

200. Liu L, Rando TA. Manifestations and mechanisms of stem cell aging. J Cell Biol. 2011;193:257-66.

201. Bigot A, Duddy WJ, Ouandaogo ZG, Negroni E, Mariot V, Ghimbovschi S, et al. Age-associated methylation suppresses SPRY1, leading to a failure of re-quiescence and loss of the reserve stem cell pool in elderly muscle. Cell Rep. 2015;13:1172-82.

202. Schultz E, Gibson MC, Champion T. Satellite cells are mitotically quiescent in mature mouse muscle: an EM and radioautographic study. J Exp Zool. 1978; 206:451-6.

203. Montarras D, L'honoré A, Buckingham M. Lying low but ready for action: the quiescent muscle satellite cell. FEBS J. 2013;280:4036-50.

204. Sudo K, Ema H, Morita Y, Nakauchi H. Age-associated characteristics of murine hematopoietic stem cells. J Exp Med. 2000;192:1273-80.

205. Beerman I, Bhattacharya D, Zandi S, Sigvardsson M, Weissman IL, Bryder D, et al. Functionally distinct hematopoietic stem cells modulate hematopoietic lineage potential during aging by a mechanism of clonal expansion. PNAS. 2010;107:5465-70.

206. Inomata K, Aoto T, Binh NT, Okamoto N, Tanimura S, Wakayama T, et al. Genotoxic stress abrogates renewal of melanocyte stem cells by triggering their differentiation. Cell. 2009;137:1088-99.

207. Martin K, Potten CS, Roberts SA, Kirkwood TB. Altered stem cell regeneration in irradiated intestinal crypts of senescent mice. J Cell Sci. 1998;111:2297-303.

208. Maslov AY, Barone TA, Plunkett RJ, Pruitt SC. Neural stem cell detection, characterization, and age-related changes in the subventricular zone of mice. J Neurosci. 2004;24:1726-33.

209. Leibovich SJ, Ross R. The role of the macrophage in wound repair. A study with hydrocortisone and antimacrophage serum. Am J Pathol. 1975;78:71-100

210. Duffield JS, Forbes SJ, Constandinou CM, Clay S, Partolina M, Vuthoori S, et al. Selective depletion of macrophages reveals distinct, opposing roles during liver injury and repair. J Clin Invest. 2005;115:56-65.

211. Takayanagi H. Inflammatory bone destruction and osteoimmunology. J Periodontal Res. 2005;40:287-93.

212. Griffin CA, Apponi LH, Long KK, Pavlath GK. Chemokine expression and control of muscle cell migration during myogenesis. J Cell Sci. 2010;123:3052-60.

213. Costamagna D, Costelli P, Sampaolesi M, Penna F. Role of inflammation in muscle homeostasis and myogenesis. Mediat Inflamm. 2015; [Cited 2019 Nov 1]. Available from: https://www.hindawi.com/journals/mi/2015/805172/.
214. Deasy BM, Feduska JM, Payne TR, Li Y, Ambrosio F, Huard J. Effect of VEGF on the regenerative capacity of muscle stem cells in dystrophic skeletal muscle. Mol Ther. 2009;17:1788-98.

215. Frey SP, Jansen H, Raschke MJ, Meffert RH, Ochman S. VEGF improves skeletal muscle regeneration after acute trauma and reconstruction of the limb in a rabbit model. Clin Orthop Relat Res. 2012;470:3607-14.

216. Rantanen J, Ranne J, Hurme T, Kalimo H. Denervated segments of injured skeletal muscle fibers are reinnervated by newly formed neuromuscular junctions. J Neuropathol Exp Neurol. 1995;54:188-94.

217. Vaittinen S, Lukka R, Sahlgren C, Hurme T, Rantanen J, Lendahl U, et al. The expression of intermediate filament protein nestin as related to vimentin and desmin in regenerating skeletal muscle. J Neuropathol Exp Neurol. 2001;60:588-97.

218. Tidball JG, Villalta SA. Regulatory interactions between muscle and the immune system during muscle regeneration. Am J Phys Regul Integr Comp Phys. 2010;298:R1173-87.

219. Gordon S, Taylor PR. Monocyte and macrophage heterogeneity. Nat Rev Immunol. 2005;5:953-64.

220. Fadok VA, Bratton DL, Guthrie L, Henson PM. Differential effects of apoptotic versus lysed cells on macrophage production of cytokines: role of proteases. J Immunol. 2001;166:6847-54.

221. Arnold L, Henry A, Poron F, Baba-Amer Y, van Rooijen N, Plonquet A, et al. Inflammatory monocytes recruited after skeletal muscle injury switch into antiinflammatory macrophages to support myogenesis. J Exp Med. 2007; 204:1057-69.

222. Patsalos A, Simandi Z, Hays TT, Peloquin M, Hajian M, Restrepo I, et al. In vivo GDF3 administration abrogates aging related muscle regeneration delay following acute sterile injury. Aging Cell. 2018;17:e12815.

223. Mounier R, Théret M, Arnold L, Cuvellier S, Bultot L, Göransson O, et al. AMPKa1 regulates macrophage skewing at the time of resolution of inflammation during skeletal muscle regeneration. Cell Metab. 2013;18:251-64.

224. Lei H, Schmidt-Bleek K, Dienelt A, Reinke P, Volk H-D. Regulatory T cellmediated anti-inflammatory effects promote successful tissue repair in both indirect and direct manners. Front Pharmacol. 2015;6 [Cited 2019 Nov 1]. Available from: https://www.ncbi.nIm.nih.gov/pmc/articles/PMC4557110/.

225. Burzyn D, Kuswanto W, Kolodin D, Shadrach JL, Cerletti M, Jang Y, et al. A special population of regulatory T cells potentiates muscle repair. Cell. 2013; 155:1282-95.

226. Gandolfo MT, Jang HR, Bagnasco SM, Ko G-J, Agreda P, Satpute SR, et al. Foxp3+ regulatory $T$ cells participate in repair of ischemic acute kidney injury. Kidney Int. 2009;76:717-29.

227. Nosbaum A, Prevel N, Truong H-A, Mehta P, Ettinger M, Scharschmidt TC, et al. Cutting edge: regulatory $T$ cells facilitate cutaneous wound healing. J Immunol. 2016;196:2010-4.

228. Raposo C, Graubardt N, Cohen M, Eitan C, London A, Berkutzki T, et al. CNS repair requires both effector and regulatory $T$ cells with distinct temporal and spatial profiles. J Neurosci. 2014;34:10141-55.

229. Weirather J, Hofmann UDW, Beyersdorf N, Ramos GC, Vogel B, Frey A, et al. Foxp3+ CD4+ T cells improve healing after myocardial infarction by modulating monocyte/macrophage differentiation. Circ Res. 2014;115:55-67.

230. Kuswanto W, Burzyn D, Panduro M, Wang KK, Jang YC, Wagers AJ, et al. Poor repair of skeletal muscle in aging mice reflects a defect in local, interleukin-33-dependent accumulation of regulatory t cells. Immunity. 2016;44:355-67.

231. Asakura A, Seale P, Girgis-Gabardo A, Rudnicki MA. Myogenic specification of side population cells in skeletal muscle. J Cell Biol. 2002;159:123-34.

232. Gussoni E, Soneoka Y, Strickland CD, Buzney EA, Khan MK, Flint AF, et al. Dystrophin expression in the $\mathrm{mdx}$ mouse restored by stem cell transplantation. Nature. 1999;401:390-4.

233. LaBarge MA, Blau HM. Biological progression from adult bone marrow to mononucleate muscle stem cell to multinucleate muscle fiber in response to injury. Cell. 2002;111:589-601.

234. Vauchez K, Marolleau J-P, Schmid M, Khattar P, Chapel A, Catelain C, et al. Aldehyde dehydrogenase activity identifies a population of human skeletal muscle cells with high myogenic capacities. Mol Ther. 2009;17:1948-58.

235. Mitchell KJ, Pannérec A, Cadot B, Parlakian A, Besson V, Gomes ER, et al. Identification and characterization of a non-satellite cell muscle resident progenitor during postnatal development. Nat Cell Biol. 2010;12:257-66.

236. Polesskaya A, Seale P, Rudnicki MA. Wnt signaling induces the myogenic specification of resident CD45+ adult stem cells during muscle regeneration. Cell. 2003;113:841-52. 
237. Torrente Y, Belicchi M, Marchesi C, D'Antona G, Cogiamanian F, Pisati F, et al. Autologous transplantation of muscle-derived CD133+ stem cells in Duchenne muscle patients. Cell Transplant. 2007;16:563-77.

238. Dammone G, Karaz S, Lukjanenko L, Winkler C, Sizzano F, Jacot G, et al. PPARy controls ectopic adipogenesis and cross-talks with myogenesis during skeletal muscle regeneration. Int J Mol Sci. 2018;19:2044.

239. Lukjanenko L, Karaz S, Stuelsatz P, Gurriaran-Rodriguez U, Michaud J, Dammone $\mathrm{G}$, et al. Aging disrupts muscle stem cell function by impairing matricellular WISP1 secretion from fibro-adipogenic progenitors. Cell Stem Cell. 2019;24:433-446.e7.

240. Birbrair A, Zhang T, Wang Z-M, Messi ML, Enikolopov GN, Mintz A, et al. Role of pericytes in skeletal muscle regeneration and fat accumulation. Stem Cells Dev. 2013;22:2298-314.

241. Rotini A, Martínez-Sarrà E, Duelen R, Costamagna D, Di Filippo ES, Giacomazzi G, et al. Aging affects the in vivo regenerative potential of human mesoangioblasts. Aging Cell. 2018;17 [Cited 2019 Jun 1] Available from: https://www.ncbi.n/m.nih.gov/pmc/articles/PMC5847873/.

242. Joe AWB, Yi L, Natarajan A, Le Grand F, So L, Wang J, et al. Muscle injury activates resident fibro/adipogenic progenitors that facilitate myogenesis. Nat Cell Biol. 2010;12:153-63.

243. Heredia JE, Mukundan L, Chen FM, Mueller AA, Deo RC, Locksley RM, et al. Type 2 innate signals stimulate fibro/adipogenic progenitors to facilitate muscle regeneration. Cell. 2013;153:376-88.

244. Contreras O, Rebolledo DL, Oyarzún JE, Olquín HC, Brandan E. Connective tissue cells expressing fibro/adipogenic progenitor markers increase under chronic damage: relevance in fibroblast-myofibroblast differentiation and skeletal muscle fibrosis. Cell Tissue Res. 2016;364:647-60.

245. Gannon WL, Sikes RS. Guidelines of the American Society of Mammalogists for the use of wild mammals in research. J Mammal. 2007;88:15.

246. Fitts DA. Ethics and animal numbers: informal analyses, uncertain sample sizes, inefficient replications, and type I errors. J Am Assoc Lab Anim Sci. 2011;50:445-53.

247. Jones S, Carley S, Harrison M. An introduction to power and sample size estimation. Emerg Med J. 2003;20:453-8.

248. Lenth RV. Some practical guidelines for effective sample size determination. Am Stat. 2001;55:187-93.

249. Charan J, Kantharia ND. How to calculate sample size in animal studies? 」 Pharmacol Pharmacother. 2013;4:303-6.

250. Festing MFW, Altman DG. Guidelines for the design and statistical analysis of experiments using laboratory animals. ILAR J. 2002;43:244-58.

251. Festing MFW. Design and statistical methods in studies using animal models of development. ILAR J. 2006;47:5-14.

252. Mead R, Gilmour SG, Mead A. Statistical principles for the design of experiments: applications to real experiments. Cambridge: Cambridge University Press; 2012. [Cited 2019 Jul 12]. Available from: http://ebooks. cambridge.org/ref/id/CBO9781139020879

253. Arifin WN, Zahiruddin WM. Sample size calculation in animal studies using resource equation approach. MJMS. 2017:24:101-5.

254. Clayton JA, Collins FS. Policy: NIH to balance sex in cell and animal studies. Nature News. 2014:509:282

255. Giordani L, He GJ, Negroni E, Sakai H, Law JYC, Siu MM, et al. Highdimensional single-cell cartography reveals novel skeletal muscle-resident cell populations. Mol Cell. 2019;74:609-621.e6.

\section{Publisher's Note}

Springer Nature remains neutral with regard to jurisdictional claims in published maps and institutional affiliations.

Ready to submit your research? Choose BMC and benefit from:

- fast, convenient online submission

- thorough peer review by experienced researchers in your field

- rapid publication on acceptance

- support for research data, including large and complex data types

- gold Open Access which fosters wider collaboration and increased citations

- maximum visibility for your research: over $100 \mathrm{M}$ website views per year

At BMC, research is always in progress.

Learn more biomedcentral.com/submissions 